\title{
Cardiovascular magnetic resonance
}

Karen G. Ordovas ${ }^{1 *}$ (D), Lauren A. Baldassarre ${ }^{2}$, Chiara Bucciarelli-Ducci ${ }^{3,4,5,6}$, James Carr ${ }^{7}$, Juliano Lara Fernandes ${ }^{8}$, Vanessa M. Ferreira ${ }^{9}$, Luba Frank ${ }^{10}$, Sophie Mavrogeni ${ }^{11,12}$, Ntobeko Ntusi ${ }^{13,14}$, Ellen Ostenfeld ${ }^{15}$, Purvi Parwani $^{16}$, Alessia Pepe ${ }^{17}$, Subha V. Raman ${ }^{18}$, Hajime Sakuma ${ }^{19}$, Jeanette Schulz-Menger ${ }^{20,21}$, Lilia M. Sierra-Galan², Anne Marie Valente ${ }^{23}$ and Monvadi B. Srichai ${ }^{24}$

\begin{abstract}
This document is a position statement from the Society for Cardiovascular Magnetic Resonance (SCMR) on recommendations for clinical utilization of cardiovascular magnetic resonance (CMR) in women with cardiovascular disease. The document was prepared by the SCMR Consensus Group on CMR Imaging for Female Patients with Cardiovascular Disease and endorsed by the SCMR Publications Committee and SCMR Executive Committee. The goals of this document are to (1) guide the informed selection of cardiovascular imaging methods, (2) inform clinical decision-making, (3) educate stakeholders on the advantages of CMR in specific clinical scenarios, and (4) empower patients with clinical evidence to participate in their clinical care. The statements of clinical utility presented in the current document pertain to the following clinical scenarios: acute coronary syndrome, stable ischemic heart disease, peripartum cardiomyopathy, cancer therapy-related cardiac dysfunction, aortic syndrome and congenital heart disease in pregnancy, bicuspid aortic valve and aortopathies, systemic rheumatic diseases and collagen vascular disorders, and cardiomyopathy-causing mutations. The authors cite published evidence when available and provide expert consensus otherwise. Most of the evidence available pertains to translational studies involving subjects of both sexes. However, the authors have prioritized review of data obtained from female patients, and direct comparison of CMR between women and men. This position statement does not consider CMR accessibility or availability of local expertise, but instead highlights the optimal utilization of CMR in women with known or suspected cardiovascular disease. Finally, the ultimate goal of this position statement is to improve the health of female patients with cardiovascular disease by providing specific recommendations on the use of CMR.
\end{abstract}

Keywords: Cardiovascular magnetic resonance, Women, Cardiovascular disease, Society for Cardiovascular Magnetic Resonance, Position statement

*Correspondence: ordovask@uw.edu

${ }^{1}$ University of Washington, Seattle, USA

Full list of author information is available at the end of the article

\section{Introduction}

Cardiovascular magnetic resonance (CMR) imaging is a robust, reproducible and safe method for non-invasive evaluation of cardiovascular diseases (CVD). Strengths of CMR include precise assessment of cardiac anatomy and function [1] and multi-parametric tissue original author(s) and the source, provide a link to the Creative Commons licence, and indicate if changes were made. The images or other third party material in this article are included in the article's Creative Commons licence, unless indicated otherwise in a credit line to the material. If material is not included in the article's Creative Commons licence and your intended use is not permitted by statutory regulation or exceeds the permitted use, you will need to obtain permission directly from the copyright holder. To view a copy of this licence, visit http://creativecommons.org/licenses/by/4.0/. The Creative Commons Public Domain Dedication waiver (http://creativeco mmons.org/publicdomain/zero/1.0/) applies to the data made available in this article, unless otherwise stated in a credit line to the data. 
characterization [2]. CMR is recommended for diagnosis and management of multiple CVDs [3-5]. CMR is particularly suitable for the evaluation of women with suspected or known CVDs given the lack of ionizing radiation exposure, which can be potentially harmful to female breast tissue $[6,7]$ or to the fetus of pregnant patients [8]. This is an advantage of CMR compared to radiation-based imaging methods including nuclear medicine scintigraphy such as single-photon emission computerized tomography (SPECT), positron emission tomography (PET), coronary computed tomography angiography (CCTA) and catheter-based X-ray angiography.

Recent advances in tissue characterization and ischemia assessment make CMR an attractive tool for imaging various pathological aspects of cardiovascular disease in women [9-13].

\section{Aims and structure of the document}

This document provides recommendations for clinical utilization of CMR in women with known or suspected CVD. We cite published evidence when available and provide expert consensus where there is paucity of evidence. Most of the evidence available pertains to translational studies involving subjects of both sexes. However, we have prioritized review of data obtained from female patients, and particularly valued the evidence providing direct comparison of CMR between women and men.

The women in CMR section of the SCMR has led various educational and advocacy initiatives to promote improved cardiovascular care of females with cardiovascular diseases. The group has recently published a comprehensive review paper highlighting the advantages of CMR for imaging cardiovascular disease in women [14]. Building on this initiative, the SCMR Consensus Group on CMR Imaging for Female Patients with Cardiovascular Disease was formed to provide guidance for current clinical CMR utilization for this purpose. Our committee is primarily composed of experts with a wide and representative range of training and expertise, a broad geographical representation and a balanced spectrum of clinicians and scientists.

The goals of this document, specific for the use of CMR in women with known or suspected CVD, are to (1) guide the informed selection of cardiovascular imaging methods, (2) inform clinical decision-making, (3) educate stakeholders on the advantages of CMR in specific clinical scenarios, and (4) empower patients with clinical evidence to participate in their clinical care.

\section{Statement of clinical utility}

1. CMR can be used to diagnose ischemic myocardial injury in women with suspected acute coronary syndrome (ACS), which is particularly important, as they are more likely to present with non-obstructive coronary arteries compared to men. In addition, CMR can reliably establish an alternate diagnosis in women with ACS symptoms and suspected diagnosis of myocardial infarction with non-obstructive coronary arteries (MINOCA), such as myocarditis and Takotsubo cardiomyopathy, which can guide subsequent management and may impact their prognosis. (Gender neutral evidence).

2. CMR is recommended for diagnosing stable ischemic heart disease (IHD) in women. Compared to other non-invasive imaging techniques, CMR provides high accuracy with no sex differences in performance for diagnosis and prognosis in identifying both macrovascular and microvascular coronary artery disease (CAD). (Gender neutral evidence)

3. CMR is the recommended method to confirm the diagnosis and severity of peripartum cardiomyopathy (PPCM). Detection of presence and extent of myocardial damage is valuable for prediction of cardiac dysfunction and risk stratification in current and future pregnancies. (Gender specific evidence)

4. CMR can be used to diagnose cancer therapy-related cardiac dysfunction (CTRCD), especially in breast cancer patients, and to confirm echocardiographydiagnosed left ventricular (LV) dysfunction. CMR is recommended for myocardial tissue characterization in the diagnosis and treatment workup to assess the etiology of cardiomyopathy. (Gender neutral evidence)

5. CMR including CMR angiography (CMRA) is the preferred imaging modality for serial concomitant assessment of aortic valve function and thoracic aorta dimensions in patients with bicuspid aortic valve (BAV) and aortopathies. (Gender neutral evidence)

6. In women who are planning to become or are currently pregnant, CMR is recommended in those with aortic syndrome, known aortic disease and congenital heart disease (CHD) when echocardiography is suboptimal. CMR provides assessment of the entire aorta, precise quantification of ventricular function, and localization of left ventricular outflow tract (LVOT) obstruction to inform decision making during pregnancy. (Gender specific evidence)

7. CMR is indicated for combined functional evaluation and tissue characterization of the myocardium and vasculature in patients with systemic rheumatic 
diseases and collagen vascular disorders, as CMR can detect associated myocardial inflammation, provides important prognostic information and may lead to changes in both cardiac and systemic treatment strategies. (Expert opinion)

8. CMR is a useful and often an essential modality for early detection of myocardial disease in female carriers of cardiomyopathy-causing mutations and could guide deployment of effective therapies. (Expert opinion)

\section{Imaging females with acute coronary syndrome Clinical scenario}

ACS is a leading cause of death worldwide [15]. ACS comprise of clinical presentation consistent with acute ischemia and includes ST-segment elevation myocardial infarction (STEMI), Non- ST-segment elevation myocardial infarction (NSTEMI) and unstable angina.

Sex differences/prevalence There are recognized sex differences in the presentation, diagnosis, management and treatment of ACS and myocardial infarction (MI) [1618]. Women are less likely to present with chest pain and often have atypical symptoms, leading to underdiagnosis, especially in younger women $[19,20]$. Women who do present to the emergency department with chest pain are investigated less aggressively than men, are less likely to receive a correct diagnosis, and are not referred as often for guideline-recommended diagnostic and/or therapeutic procedures [21]. Women with ACS are not as likely to have significant obstructive $\mathrm{CAD}$ on invasive coronary angiography and more likely to have ruptured plaque, plaque erosion, or thrombus formation [22, 23]. Among women with MI and MINOCA, a significant proportion show biochemical or imaging evidence of myocardial ischemia [22]. Spontaneous coronary artery dissection [24], coronary thromboembolism, coronary artery vasospasm, microvascular dysfunction, and Takotsubo stressinduced cardiomyopathy, are a few of the ACS etiologies that need special consideration in women.

Traditional evaluation The standard work-up includes assessment of risk factors, history and physical examination, blood biomarkers for cardiomyocyte damage (e.g., troponins) and the electrocardiogram (ECG), Invasive coronary angiography, non-invasive cardiac imaging modalities such as echocardiography, CCTA and CMR. Advanced coronary imaging techniques such as optical coherence tomography (OCT), intravascular ultrasound (IVUS) are the cornerstone of diagnosis in cases with ACS with no or $<50 \%$ obstructive CAD. These tests may help confirm, refine or reclassify the initial diagnosis, which determines treatment pathways and outcomes.

Benefits for use of CMR (gender neutral evidence) CMR provides significant incremental value to conventional tests in establishing an accurate diagnosis [25-27] and prognosis in ACS [28]. CMR plays an important role in the contemporary assessment and prognosis of MINOCA [26, 29-31]. CMR allows detection of small MIs, distinguishing between left anterior descending coronary artery (LAD) territory infarction and Takotsubo cardiomyopathy, and differentiating MI from myocarditis. Since women are more likely to present in an atypical manner, they should be approached differently than men. CMR may help to confirm (or exclude) a diagnosis of $\mathrm{ACS}$, so that physicians may provide appropriate timely treatment.

\section{Suggested protocol}

- Balanced steady-state free precession (bSSFP) cine (short and long axis planes) for evaluation of cardiac structure, function and potential mechanical complications from acute $\mathrm{MI}$

- T2-weighted (T2w) imaging for edema imaging according to current expert recommendations [30]

- $\mathrm{T}^{*}$ mapping for detection of intramyocardial hemorrhage[32] (optional)

- T1-weighted (T1w) late gadolinium enhancement (LGE) is the recommended methodology to estimate the extent of acute myocardial necrosis and microvascular obstruction (MVO) [32]

- T1w early gadolinium enhancement (EGE) may detect LV intracavitary thrombus (can also visualize MVO) (optional)

- In stable patients outside of the acute phase, consideration should be given to vasodilatory stress perfusion imaging (adenosine, regadenoson, dipyridamole) with gadolinium based contrast agent (GBCA) to assess for the functional significance of any bystander CAD, and, in particular, microvascular dysfunction.

- Parametric mapping techniques (T1/T2/ extracellular volume fraction (ECV)) are emerging CMR technologies that hold promise in providing more sensitive detection of acute myocardial injury, including assessment of the extracellular volume and myocardial interstitium that may provide further insights into differences between women and men who present with ACS. 


\section{Stable ischemic heart disease-imaging ischemia}

Clinical scenario: IHD is the leading cause of cardiovascular death worldwide [33]. Stable IHD includes patients who have had ACS or are at risk for ACS, even if they have no or limited symptoms. In 2015, there was an estimated 110 million patients with IHD worldwide. IHD accounts for the majority of CVD in patients over 40 years, with steady increase in prevalence with age [34]. Early detection of these patients is important to decrease morbidity and mortality [35]

Sex differences/prevalence: Women have slightly lower prevalence of IHD, but higher mortality rate and complications, indicating a potential gap in accurate diagnosis and management strategies specific to women [15]. In comparison to men, female specific features include a higher proportion of symptomatic patients with nonobstructive CAD and microvasculature dysfunction [36], and more frequent presentation with "atypical" angina symptoms [37]. As a result, women tend to receive less intensive care that lead to higher morbidity, including heart failure, and mortality compared to men [38, 39].Given the higher dissociation between symptoms, ischemia burden and obstructive versus non-obstructive CAD in women, a more sensitive and "specific" functional evaluation of IHD is warranted for tailored therapeutic decisions [40].

Traditional evaluation: Diagnostic testing is recommended in symptomatic stable patients with suspected or known IHD and change in clinical status. Functional assessment for ischemia with stress testing with or without imaging is the most common method of evaluation. The advent of CCTA allows for direct, noninvasive evaluation of the underlying anatomic coronary features in IHD and provides an alternative diagnostic method [35].

Benefits for use of CMR (gender neutral evidence): Poorly calibrated pre-test probability tables in addition to limitations with achievement of maximum exercise capacity are factors that lead to the relatively low diagnostic yield of traditional tests like exercise treadmill stress test and stress echocardiography for females with IHD [41, 42]. CCTA provides high anatomic correlation with invasive X-ray coronary angiography, but given the higher dissociation between symptoms, ischemia burden and obstructive versus non-obstructive CAD in women, functional evaluation of IHD is still warranted for proper therapeutic management decisions (Class I, level of evidence B) [43, 44], especially for women. CMR has many advantages over other modalities including the lack of ionizing radiation, greater sensitivity independent of the prevalence of the disease compared to SPECT with no sex differences in diagnostic performance [45], ability to identify microvascular dysfunction and provide automated quantitative evaluation of global and regional perfusion [46, 47], identification of concurrent myocardial scar [9, 48-50], and comprehensive evaluation to exclude other cardiac (myocardium, pericardium, valves or great vessels) causes of chest pain. While exercise stress CMR can be performed with suitable accuracy [51], more common approaches involve vasodilator stress CMR using adenosine, regadenoson or dipyridamole [41]. In the latest version of the 2004 American College of Cardiology/American heart Association (ACC/AHA) guidelines for stable CAD, pharmacological stress CMR is recommended for: diagnosis of IHD in patients with either known or intermediate to high pretest probability of IHD who are unable to exercise or have uninterpretable ECG (Class IIa, level of evidence B); risk assessment in patients with known CAD being considered for revascularization with unclear physiologic stenosis (Class I, level of evidence $\mathrm{B}$ ); and follow-up of revascularized stable CAD in symptomatic patients (Class I, level of evidence C) [35, 42]. In the 2019 guidelines from the European Society of Cardiology (ESC) of chronic CAD, CMR is recommended for evaluation of patients with suspected coronary microvascular angina (Class IIb, level of evidence B) [44].

\section{Suggested protocol}

- Rest bSSFP cine (short and long axis planes) for evaluation of cardiac structure and function

- Vasodilator stress using conventional doses and protocols: induced vasodilation (adenosine, regadenoson, dipyridamole) [52]

- Stress first pass perfusion imaging; automated quantitative perfusion mapping is recommended if available

- T1w LGE (short and long axis planes)

- Native T1-mapping and stress T1-mapping are emerging technologies that may play a role in the GBCA-free CMR assessment of ischemic heart disease $[53,54]$. ECV may serve as surrogate marker for diffuse fibrosis, although resting coronary vasodilation associated with ischemia may expand the intravascular compartment (thus ECV) in the ischemic territory. 


\section{Peripartum cardiomyopathy}

Clinical scenario: Peripartum cardiomyopathy (PPCM) is a rare form of dilated cardiomyopathy characterized by LV systolic dysfunction and LV ejection fraction (LVEF) $<45 \%$ occurring during late pregnancy or in the months following delivery in previously healthy women without a history of heart disease. Right ventricular (RV) systolic dysfunction may be noted in up to $35 \%$ of PPCM patients [55] and is linked to worse prognosis than isolated LV involvement. Symptoms are non-specific, such as shortness of breath, cough, orthopnea, and hemoptysis. Patients may also present with arrhythmias, embolic events, and myocardial infarction.

Multiple theories exist to explain PPCM, including genetic predisposition, apoptosis, and abnormal immune response to fetal microchimerism, abnormal hemodynamic response, prolonged tocolysis, and ethnicity, among others [56]. Risk factors predisposing for PPCM are advanced age, multiparity and twin pregnancies, African American ethnicity, hypertension, and preeclampsia [57]

Prevalence: PPCM is a female specific disease with mixed and inconsistent reports of incidence. Two of the largest population-based studies by Mielniczuk, [58] and Brar [59] report mortality of $2.05 \%$ in a retrospective study of 3.6 million patients, with an incidence of approximately 1 per 3189 live births [55] and mortality of 3.3\% in 241,497 patients with an incidence of 1 in 4025 live births. Incidence greatly varies by ethnicity, with lowest reported among Hispanic women and highest among African American women.

Traditional evaluation: PPCM is diagnosed during current or recent pregnancy and symptoms of heart failure in previously healthy woman, family history of heart disease, abnormal ECG, elevated troponins, and $\mathrm{N}$-terminal pro-B-type natriuretic peptide (NT-proNBP). Imaging assessment of PPCM is performed using echocardiography as the primary modality, CMR for confirmation of diagnosis and assessment of severity, and rarely cardiac catheterization/endomyocardial biopsies. Therapeutic interventions consider wellbeing of both mother and the fetus by informing best type and dosage of medications. Some patients require continuous monitoring until improvement of cardiac function is achieved.

Benefits for use of CMR in this scenario (gender specific evidence): Assessment of heart disease without ionizing radiation exposure make CMR an optimal imaging modality in pregnancy. Furthermore, CMR helps evaluate the other etiology for dilated cardiomyopathy. Comprehensive assessment of cardiac function and myocardial damage by CMR assists planning and follow-up management of PPCM along with prediction of possible PPCM in subsequent pregnancies. The pattern of LGE in PPCM is nonspecific and often similar to idiopathic nonischemic cardiomyopathy. While some studies failed to demonstrate presence of LGE in peripartum cardiomyopathy [60], others report LGE in up to $40 \%$ of cases [61].When present, pattern of LGE shows focal and linear distribution, involving mid myocardial wall and sub-epicardium [60]61. The presence of LGE is associated with increased risk of heart failure decompensation during delivery, increased rate of readmissions, and increased risk for exacerbation during recurrent pregnancies [62]. Inflammatory reaction should be assessed to characterize reversible injury.

\section{Suggested protocol}

- bSSFP cine (short and long axis planes) for evaluation of cardiac structure and function

- Detection of myocardial inflammation/edema using a T2-based method (e.g., T2w imaging or T2-mapping)

- Detection of myocardial edema, hyperemia/capillary leak, necrosis and fibrosis using a T1-based method (e.g., EGE, T1-mapping, ECV and/or T1w LGE) according to current expert recommendations [63]

\section{Assessment of cancer therapy-related cardiac dysfunction (CTRCD) in breast cancer patients}

Clinical scenario: Chemotherapy, radiation therapy, and targeted agents have led to significant improvements in the survival rate of women with breast cancer [64]. However, these therapies are associated with on-target and off-target cardiac side effects, leading to CTRCD and substantial cardiac morbidity and mortality. 5-year cumulative incidence of heart failure and cardiomyopathy in women receiving combination therapy ranged from $7.5 \%$ in the young to $36 \%$ in the older patients [65]. In the latter, CVD is the leading cause of death (15.9\%), with breast cancer being close but second (15.1\%) [66].

Prevalence: Breast cancer is a female predominant disease, affecting about 1 in 8 women over the course of their lifetime, whereas the risk is 1 in 1000 for men [64]. There are reported sex disparities in the incidence of cancers in other organs, with generally higher incidence 
in men for most malignancies except for thyroid cancer which is more prevalent in women [67].

Traditional evaluation: Guideline driven evaluation and monitoring of cardiac function of women undergoing oncologic treatment is traditionally performed with transthoracic echocardiography (TTE), and preferably with three-dimensional (3D) LVEF and LV strain assessment [68-70]. A 10\% change in LVEF may dictate the therapeutic regimen [70]. However, up to $25 \%$ of patients with cardiac dysfunction (LVEF $<50 \%)$ are missed with two-dimensional (2D) TTE [71]. In addition, 2D echocardiography has higher temporal variability $(9.8 \%)$ than $3 \mathrm{D}$ echocardiography (5.6\%) [72].which should be kept in mind when evaluating these patients. LVEF can equally be assessed accurately with multi-acquisition gated angiography (MUGA) as well as CMR and 3D echocardiography [73]. However, MUGA is not preferred owing to the ionizing radiation, which is a significant concern in women with breast cancer.

Benefits for use of CMR in this scenario (gender neutral evidence): CMR can be used as a first line method or when echocardiographic image quality is inadequate for volumetric and functional assessment of patients at risk for CTRCD, according to societal guidelines [74]. Furthermore, when echocardiography is abnormal (e.g., change in LVEF), CMR should be performed to confirm the altered LVEF prior to making decisions about management. Additionally, CMR should be used for tissue characterization and evaluation of ischemic and non-ischemic scar or fibrosis and inflammation, such as may occur in trastuzumab related cardiomyopathy and immune-checkpoint inhibitor myocarditis [75]. CMR strain imaging has been shown to decrease post anthracycline use [76] although currently no inter-vendor normal reference values has been established to guide management. T2w imaging with increased signal intensity have been observed in patients post anthracycline and trastuzumab [77, 78]. T1 mapping and ECV has been observed to increase after anthracycline exposure [79, 80], although their clinical significance and influence on patient management is yet to be determined. Stress perfusion CMR to detect or exclude functionally significant CAD in women [45] should be added if there is suspicion for or if necessary to exclude CAD prior to proceeding with surgery or other therapy where indicated.

\section{Suggested protocol}

- Non-contrast study for those receiving serial imaging for screening of LV dysfunction in lieu of echocardiography
- bSSFP cine (short and long axis planes) for evaluation of cardiac structure and function

- Consider further tissue characterization for myocardial inflammation and other changes using T2w imaging and/or parametric T1/T2 mapping and ECV (optional)

- T1w LGE in suspected cardiomyopathy

- Stress first-pass perfusion to assess for functionally significant CAD prior to surgery or other therapy if indicated

\section{Baseline and follow aortic assessment in bicuspid aortic valve}

Clinical scenario: Bicuspid aortic valve (BAV) disease affects $0.5-1 \%$ of the population with a male predominance of 3:1 [81]. BAV is associated with aortic valve dysfunction (i.e. stenosis or regurgitation) and thoracic aortic disease, including ascending aortic aneurysm and aortic dissection [82]. Thoracic aortic dilatation is thought to be independent of degree of valve stenosis and has been associated with reduced fibrillin in the aortic wall and/or genetic defects (e.g. NOTCH 1 gene) [83]. Many women with BAV are asymptomatic, however, when they do develop symptoms, they are related to aortic valve dysfunction, aortopathy (i.e., aneurysm, dissection) and acquired conditions such as endocarditis. Guidelines recommend screening first-degree relatives of patients with BAV for BAV and associated aortopathy [84]. Patients with BAV should be monitored for progressive aortic valve dysfunction and aortic disease. Surveillance is commonly performed with serial imaging at intervals between 6 months and 5 years depending on patient age and degree of underlying pathology $[84,85]$.

Sex differences/prevalence: Morphology type of BAV is similar between men and women. At initial presentation, men more frequently demonstrate moderate to severe aortic regurgitation, whereas women more commonly show moderate to severe aortic stenosis. Women are less likely to develop endocarditis or concomitant aortopathy compared to men [86, 87]. Despite less baseline morbidity compared to men, women exhibit a significantly higher mortality in tertiary and surgical referral cohorts, which can be independently predicted by presence of significant aortic regurgitation and/or New York Heart Association (NYHA) Class 3 or 4 heart failure symptoms [87]. The reasons for the excess mortality in women may relate to use of absolute as opposed to indexed cutoff values for referral to aortic valve or aorta surgery in which men will reach earlier than women as they have larger 
body surface area (BSA) values. Pregnancy in women with BAV is associated with an increased risk for complications [88] and women who may become or are pregnant should receive appropriate counseling (see section on "Pregnancy risk stratification for congenital heart disease and aortopathy").

Traditional evaluation: Echocardiography is the preferred method for diagnosing BAV disease with reported high sensitivity, although diagnosis can be limited in patients with heavily calcified valves [89]. Visualization of the thoracic aorta is limited to the aortic root and ascending aorta with TTE. If the ascending aorta is not well visualized on echocardiography, then computed tomography angiography (CTA) or magnetic resonance angiography (MRA) is recommended. ECG gated CTA provides excellent visualization of the entire thoracic aorta with high resolution but has the disadvantage of radiation exposure and requirement for iodinated contrast. Assessment of the aortic valve with CTA requires a retrospectively gated acquisition, generally associated with higher radiation exposure, which is particularly relevant in young women exposure of the breast tissue (see section on "Radiation"). For patients with BAV, annual CTA or MRA is recommended if aortic root or ascending aorta is $3.5-4.4 \mathrm{~cm}$, and with echocardiography to follow valve disease, if needed; for dimensions of $4.5-5 \mathrm{~cm}$, biannual CTA or MRA is recommended.

Benefits for use of CMR (gender neutral evidence): CMR and MRA have the advantage of providing a comprehensive assessment of the aortic valve and the entire thoracic aorta in a single examination without radiation exposure. Direct planimetric measurement of the aortic valve area can be achieved using bi-orthogonal short axis cine images of the aortic valve. Non-contrast MRA techniques are available which mitigates any risk related to gadolinium deposition, which may be of particular concern with serial surveillance.

\section{Suggested protocol}

- bSSFP cine (short and long axis planes) for evaluation of cardiac structure and function. Multiplanar bSSFP cine with specific views of the aortic valve and aorta

- Axial T1w fast spin echo through aorta (optional, for intramural hematoma, dissection)

- Axial T2w gradient echo through aorta (optional, for aortitis)

- 2D phase contrast velocity encoding at aortic root for aortic flow (or four-dimensional flow if available)
- 3D contrast enhanced or non-contrast MRA of the thoracic aorta

- Orthogonal dimensions of the aorta should be obtained from 7 anatomic landmarks in the thoracic aorta, according to the American Heart Association guidelines [90]

\section{Pregnancy risk stratification for congenital heart disease and aortopathy}

Clinical scenario: CVD is a leading cause of morbidity and mortality in pregnant women [91]. Women with CVD particularly women with congenital heart disease (CHD) who are contemplating pregnancy should undergo a complete work-up including appropriate cardiac imaging for risk stratification prior to conception. For women with connective tissue disorders, pregnancy may be associated with progressive dilatation of the aorta secondary to estrogen effects, increased protease activity in the extracellular matrix and defective collagen synthesis [92]. Aortic dissection remains the greatest concern as it is associated with high maternal mortality, with increased risk in both the antepartum and postpartum periods [93]. Syndromes with high risk for aortic dissection include Marfan [94], Loeys-Dietz and Ehler Danlos type IV (vascular type). Other syndromes in which there is an increased risk of dissection include BAV and Turner syndrome. In women with Marfan syndrome, the aortic root size may not return to the pre-pregnancy dimensions and there appears to be an increased risk of future aortic events or need for aortic root replacement after pregnancy [95].

Prevalence: Approximately 1-4\% of pregnant women have underlying CVD [96]. The rising incidence of CVD in pregnancy is related to a number of factors including advancing maternal age with associated increased prevalence of CVD risk factors and increasing number of women with CHD who reach childbearing age. CHD comprises at least 50\% of CVD in pregnancy [97].

Traditional evaluation: Imaging is an important component of the evaluation before and during pregnancy [98]. Several risk stratification models have been developed summarizing maternal and fetal outcomes in women with CVD [99]100. Specific imaging factors included in these models that confer a higher risk of adverse events in pregnancy include depressed systemic ventricular function, obstructive morphology, pulmonary hypertension and aortopathy $[100,101]$.While TTE remains the first line imaging modality for CVD in pregnancy, many 
women with CHD undergo CMR for cardiovascular surveillance and risk stratification prior to pregnancy [98]

Benefits for use of CMR (gender specific evidence): In specific CHD populations, CMR studies have identified risk factors for adverse maternal outcomes in pregnancy. As an example, descending thoracic aortic diameter $<1.2 \mathrm{~cm}$ was correlated with higher maternal cardiovascular events in patients with aortic coarctation [99] and maternal cardiac events (cardiac arrest and arrhythmias) were associated with a systemic RV ejection fraction (RVEF) of $<35 \%$ [99] in women with atrial switch procedure for transposition of great arteries. CMR is particularly useful in women with aortic disease during pregnancy. The 2018 ESC Guidelines for Management of Cardiovascular Disease during Pregnancy states that imaging of the entire aorta with CMR or CTA is recommended before pregnancy in patients with a genetically proven aortic syndrome or known aortic disease (Class I, level of evidence C). During pregnancy, CMR (without GBCA) is recommended for imaging the distal ascending aorta, aortic arch, or descending aorta (Class I, level of evidence C) or when other non-invasive diagnostic testing is not sufficient for definitive diagnosis (Class IIa, level of evidence C) $[96,102]$. The use of GBCA should be avoided, if possible, especially in the first trimester. A recent multicenter study including 83 pregnant women with vascular disease, CHD and cardiomyopathies has shown that management plans were changed in $35 \%$ of patients based on the CMR findings [103].

\section{Suggested protocol}

- Patients should be imaged supine position.

- For patients $>20$ weeks' gestation, the use of a wedge or pillow under right buttock to tilt pelvis off the vena cava is recommended.

- If GBCA is necessary to answer the clinical question, a low-risk agent with the minimum possible amount should be used.

- 3D MRA of the chest can be performed with GBCA or using inherent increased signal of the blood pool with navigator-compensated and ECG-gated 3D bSSFP sequence.

- bSSFP cine sequences in the axial, oblique sagittal, and aortic orifice view planes are useful for precise measurement of maximum aortic size, particularly at the sinus of Valsalva where the most motion artifact is seen with standard 3D MRA.

- bSSFP cine (short and long axis planes) for evaluation of cardiac structure and function

- If there are concerns about the patient, communication with the obstetrical team is critical.
- Parametric T1 and T2 mapping holds promise to provide GBCA-free myocardial tissue characterization in the future, and may be particularly suitable for this patient group.

\section{Cardiovascular assessment in patients with systemic diseases}

Clinical scenario: Rheumatoid arthritis, spondyloarthropathies, systemic lupus erythematosus, systemic vasculitis, inflammatory myopathies, systemic sclerosis and mixed connective tissue disease are autoimmune rheumatic diseases (ARD) with high incidence of CVD [104]. Although targeted treatment has significantly decreased the disease-related mortality, life expectancy in ARD patients still remains low compared to the general population [105], mainly due to increased CVD [106-110]. There are several pathophysiologic processes that contribute to the development of CVD in patients with ARD, including myocardial/vascular inflammation [111-113], macro- and micro- vasculopathy [114, 115], and small epicardial, intramyocardial and/or subendocardial fibrosis due to inflammation and/or myocardial infarction $[114,116,117]$. These processes are not well evaluated by traditional imaging techniques, and an ideal diagnostic evaluation would include assessment of the acuity of heart involvement $[113,118,119]$ and angiography of the great vessels with assessment of the arterial wall inflammatory process [116]. Iron overload states represent another relevant systemic disease that can affect the heart. Iron overload cardiomyopathy (IOC) results from genetic iron metabolism disorders (primary hemochromatosis) or multiple transfusions (thalassemia or myelodysplasia).

Sex differences/prevalence: ARD affect $8 \%$ of the population and approximately $78 \%$ of patients are women [120]. Sex differences are the result of various factors, including sex hormones, microchimerism, genes on $\mathrm{X}$ or $\mathrm{Y}$ chromosomes, $\mathrm{X}$ chromosome inactivation and differing responses to environmental factors. Estrogens may directly increase ARD in women by elevating autoantibodies and amplifying autoreactive $\mathrm{T}$ - and $\mathrm{B}$-cell responses [121]. Myocardial iron overload (MIO) is seen approximately $30 \%$ of patients with thalassemia [122, 123] Although men and women have a similar risk of iron accumulation, women have significant lower risk for cardiac dysfunction, heart failure and arrhythmias compared to men[122]. 
Traditional evaluation: The standard evaluation of ARD patients with suspected CVD often includes clinical history and examination, ECG, TTE, 24-h cardiac ECG monitoring, nuclear imaging and invasive $\mathrm{x}$-ray coronary angiography, if necessary. However, the silent presentation of cardiac involvement in ARD patients is difficult to detect and may hamper comprehensive clinical evaluation and treatment. The limited tissue characterization of TTE leads to under-diagnosis of early myocardial involvement, which may lead to fatal arrhythmias despite preserved LV and RV function [124]. Nuclear imaging techniques may miss small perfusion/fibrosis defects due to inherently low spatial resolution. Annual ECG, $24 \mathrm{~h}$ ECG monitoring, and TTE are generally used in the evaluation and follow-up of patients with suspected MIO.

Benefits for use of CMR (expert opinion): CMR provides significant advantages over other imaging techniques in the assessment of CVD in ARD patients, owing to CMR's high spatial resolution and ability to detect small myocardial and vascular changes. In patients with suspected IOC, the highly reproducible and sensitive CMR T2* technique has revolutionized management, providing noninvasive, quantitative and validated $\mathrm{MIO}$ assessment $[118,125,126]$. Initial cardiac T2* assessment should be performed as early as possible in the course of the disease. Annual CMR assessment is recommended, but can be repeated every 2 years in patients without MIO or in women given the lower CVD risk $[126,127]$. Precise assessment of degree of iron deposition that can inform chelation therapy in patients with MIO. Comprehensive CMR examination allows for evaluation of the various pathophysiologic processes that may be present in patients with ARD and MIO. CMR adds to the diagnosis and management of CVD in ARD and MIO based on the assessment of myocardial ischemia and replacement or diffuse fibrosis [115, 117, 119, 128-130], disease acuity and extent [112,114, 117, 128-132] due to either macro- or micro-vascular coronary artery disease. It also helps with etiology of silent/overt heart failure or rhythm disturbances [112, 133].High accuracy of stress CMR is valuable for early assessment of CAD [117].

\section{Suggested protocol}

- bSSFP cine (short and long axis planes) for evaluation of cardiac structure and function

- Detection of myocardial edema/inflammation using a T2-based method (e.g. T2w imaging or T2-mapping) according to current expert recommendations [63]

- Detection of myocardial edema, hyperemia/capillary leak, necrosis and fibrosis using a T1-based method (e.g., early gadolinium enhancement, T1-mapping, ECV and/or T1w LGE) according to current expert recommendations [63]

- Stress-rest first pass perfusion for evaluation of myocardial ischemia (optional, if there is relevant clinical question)

- T2* mid short axis (optional basal, mid and apical short axis) when MIO is suspected

\section{CMR in female carriers of heritable cardiomyopathies}

Clinical scenario: A genetic carrier is an individual with a mutation, typically recessive, in an allele or one copy of a gene [134]. Female carriers differ from males in recessive mutations on the $\mathrm{X}$ chromosome. Historically, female cardiogenetic carriers were thought to be immune to $\mathrm{X}$-linked disease manifestations, having $2 \mathrm{X}$ chromosomes. However, carriers may incur mild to severe phenotypic changes with mutations for dilated (such as Duchenne and Becher muscular dystrophy [135] and Danon's disease [136] and hypertrophic (e.g. AndersonFabry disease) cardiomyopathies [137]. Disease penetrance often occurs later in life for carrier women vs. affected men. Cardioprotective therapies have been proven efficient when structural or functional abnormalities are present, even prior to symptom onset-a state known as 'stage B cardiomyopathy' [138]. Thus, clinical recognition of carrier status is important to facilitate cardiac risk assessment and management. With increasing acknowledgement of the risk of cardiomyopathy in female carriers, early detection with CMR provides guidance for deployment of effective therapies in female carriers of cardiomyopathy-causing mutations.

Prevalence: The prevalence of mutations that place women at risk of cardiomyopathy is not known but likely under-recognized, and genetic testing remains limited in its use to evaluate 'idiopathic' cardiomyopathy. Genetic testing of mothers or female siblings of males with $\mathrm{X}$-linked cardiomyopathies are recommended and should be more widely practiced $[68,135-140]$.

Traditional evaluation: Female carriers may be screened by compiling a pedigree, clinical history, physical examination, ECG, and imaging, typically TTE. In the absence of cardiac symptoms, carriers may undergo no further testing. However, CMR is variably used to screen asymptomatic carriers or evaluate those with symptoms.

Benefits for use of CMR in this scenario (expert opinion): CMR uniquely identifies myocardial changes resulting 
in female carriers well before typical measures of cardiac function are abnormal. Tissue characterization coupled with biventricular function quantification constitutes the major benefit of using CMR. Female mutation carriers of Duchenne, Danon and Anderson-Fabry's diseases have varying degrees of myocardial damage by CMR even with normal LV size and function, before apparent heart failure or sudden death occur $[136,137,141]$

\section{Suggested protocol}

- bSSFP cine imaging for cardiac functional and volumetric assessment according to societal guidelines [74]

- T1w LGE, typically showing epicardial or midwall fibrosis in X-linked cardiomyopathies, and to exclude ischemic damage $[42,140]$

- Further tissue characterization using Tw imaging and/or parametric T1/T2 mapping, particularly T1 mapping in Anderson-Fabry disease carriers [142] or in unclear LV hypertrophy

\section{Safety considerations related to magnetic field and contrast media}

\section{i. Magnetic field considerations}

CVD remains a major cause of morbidity and mortality in pregnant and post-partum women [143]. Although pregnancy is not a contraindication to magnetic resonance imaging (MRI), heating by radiofrequency pulses and effects of acoustic noise on the fetus have been raised as potential concerns. However, a retrospective study in 754 neonates who had $1.5 \mathrm{~T}$ MRI in utero showed no effect on hearing function or birth weight compared to control neonates [144]. Further in a large retrospective study in Canada that analyzed 1737 pregnancies with MRI, an exposure to MRI was not associated with a higher risk of stillbirth or neonatal death, congenital abnormalities, neoplasm or hearing loss when compared to 1.4 million pregnancies without MRI [145]. Therefore, recent results suggested that non-contrast enhanced MRI appears to be safe in pregnant women. Of note, due to increased heating effect and lack of safety data at $3 \mathrm{~T}$, it is recommended to avoid MRI at $>1.5 \mathrm{~T}$ during pregnancy.

\section{ii. Contrast media considerations}

GBCA can cross the placenta and is excreted by the fetal kidneys into the amniotic fluid, and then returns to the fetal circulation by swallowing. Although the amounts of gadolinium chelate in the fetal tissues and amniotic fluid were much smaller than the maternal injected dose, prolonged recirculation of the contrast medium in fetal tissue can cause adverse effects [146]. In a retrospective study of Canadian provincial pregnancies from 2003 to 2015, GBCA MRI during pregnancy was associated with higher risk of stillbirth or neonatal death and a broad set of rheumatological, inflammatory, or infiltrative skin conditions, compared to the control group who did not undergo MRI during pregnancy [145]. Accordingly, GBCA should only be used if contrastenhanced CMR is considered critical and the potential benefits justify the potential risk to the fetus [147]. When there is a very strong indication for contrast-enhanced CMR, the smallest possible dose of a macrocyclic GBCA may be given to the pregnant women [146].

Previously, some centers have recommended avoidance of breast feeding for $24 \mathrm{~h}$ after administrating GBCA in lactating women. However, less than $0.04 \%$ of the total maternal dose of intravenous GBCA passes into the breast milk over $24 \mathrm{~h}$, with only a small fraction of this amount absorbed from the gastrointestinal tract [148]. Therefore, according to the current guidelines [146, 147], breast feeding may be continued when macrocyclic GBCA are given to the mother.

\section{Conclusion}

This document summarizes the recommendations of the SCMR Consensus Group on CMR Imaging for Female Patients with Cardiovascular Disease. After thorough review of current evidence and major society guidelines, and input from experts in the field, the group has proposed eight clinical applications where CMR is particularly useful in the assessment of female cardiovascular diseases.

The position statement does not consider CMR accessibility or availability of local expertise, but instead highlights the optimal utilization of CMR in women with cardiovascular disease. Finally, the ultimate goal of this position statement is to improve the health of female patients with cardiovascular disease by providing specific recommendations on use of CMR.

\footnotetext{
Abbreviations

2D: Two-dimensional; 3D: Three-dimensional; ACC: American College of Cardiology; ACS: Acute coronary syndrome; AHA: American Heart Association; ARD: Autoimmune rheumatic diseases; BAV: Bicuspid aortic valve; BSA: Body surface area; bSSFP: Balanced steady state free precession; CAD: Coronary artery disease; CCTA: Coronary computed tomography angiography; CHD: Congenital heart disease; CMR: Cardiovascular magnetic resonance; CTA: Computed tomography angiography; CTRCD: Cancer therapy-related cardiac dysfunction; CVD: Cardiovascular disease; ECG: Electrocardiogram; ECV: Extracellular volume fraction; ESC: European Society of Cardiology; GBCA: Gadolinium based contrast agent; IHD: Ischemic heart disease; IOC: Iron overload cardiomyopathy; IVUS: Intravascular ultrasound; LAD: Left anterior descending coronary artery; LGE: Late gadolinium enhancement; LV: Left ventricle/left ventricular; LVEF: Left ventricular ejection fraction; LVOT: Left ventricular outflow tract; MI: Myocardial infarction; MIO: Myocardial iron overload; MINOCA: Myocardial infarction with non-obstructive coronary arteries; MRA: Magnetic resonance
} 
angiography; MRI: Magnetic resonance imaging; MUGA: Multi-acquisition gated angiography; MVO: Microvascular obstruction; NSTEMI: Non-STsegment elevation myocardial infarction; NYHA: New York Heart Association; OCT: Optical coherence tomography; PET: Positron emission tomography; PPCM: Peripartum cardiomyopathy; RV: Right ventricle/right ventricular; RVEF: Right ventricular ejection fraction; SCMR: Society for Cardiovascular Magnetic Resonance; SPECT: Single-photon emission computerized tomography; STEMI: ST-segment elevation myocardial infarction; T1 w: T1-weighted; T2w: T2 weighted; TTE: Transthoracic echocardiography.

\section{Acknowledgements}

None.

\section{Authors' contributions}

$\mathrm{KGO}$ and $\mathrm{MBS}$ were responsible for the integrity of the entire manuscript and for submission to the SCMR publications committee for review. All authors were major and equal contributors in writing this manuscript. All authors read and approved the final manuscript.

\section{Funding}

No funding was provided for this project.

\section{Availability of data and materials}

Data sharing not applicable to this article as no datasets were generated or analysed during the current study.

\section{Declarations}

Ethics approval and consent to participate

Not applicable.

\section{Consent for publication}

Not applicable.

\section{Competing interests}

CBD: CEO (part-time) of the Society for Cardiovascular Magnetic Resonance. $J$ LF: Research agreements with Siemens AG.

\section{Author details}

${ }^{1}$ University of Washington, Seattle, USA. ${ }^{2}$ Yale University, New Haven, CT, USA. ${ }^{3}$ Bristol Heart Institute, Bristol, UK. ${ }^{4}$ Bristol National Institute of Health Research (NIHR) Biomedical , Research Centre, Bristol, UK. ${ }^{5}$ University Hospitals Bristol, Bristol, UK. ${ }^{6}$ University of Bristol, Bristol, UK. ${ }^{7}$ Department of Radiology, Northwestern University Feinberg School of Medicine, Chicago, IL, USA. ${ }^{8}$ Jose Michel Kalaf Research Institute, Radiologia Clinica de Campinas, São Paulo, Brazil. ${ }^{9}$ Oxford Centre for Clinical Magnetic Resonance Research (OCMR), Division of Cardiovascular Medicine, British Heart Foundation Centre of Research Excellence, Oxford NIHR Biomedical Research Centre, University of Oxford, Oxford, UK. ${ }^{10}$ Medical College of Wisconsin, Wisconsin, USA. ${ }^{11}$ Onassis Cardiac Surgery Center, Athens, Greece. ${ }^{12}$ Kapodistrian University of Athens, Athens, Greece. ${ }^{13}$ University of Cape Town, Cape Town, South Africa. ${ }^{14}$ Groote Schuur Hospital, Cape Town, South Africa. ${ }^{15}$ Department of Clinical Sciences Lund, Clinical Physiology, Skåne University Hospital Lund, Lund University, Lund, Sweden. ${ }^{16}$ Division of Cardiology, Department of Medicine, Loma Linda University Health, Loma Linda, CA, USA. ${ }^{17}$ Magnetic Resonance Imaging Unit, Fondazione G. Monasterio C.N.R., Pisa, Italy. ${ }^{18}$ Krannert Institute of Cardiology, Indiana University, Indianapolis, USA. ${ }^{19}$ Department of Radiology, Mie University School of Medicine, Mie, Japan. ${ }^{20}$ harite Hospital, University of Berlin, Berlin, Germany. ${ }^{21}$ HELIOS-Clinics Berlin-Buch, Berlin, Germany. ${ }^{22}$ American British Cowdray Medical Center, Mexico City, Mexico. ${ }^{23}$ Boston Children's Hospital, Brigham and Women's Hospital, Boston, USA. ${ }^{24}$ Georgetown University School of Medicine, Washington, USA.

Received: 21 February 2021 Accepted: 17 March 2021 Published online: 10 May 2021

\section{References}

1. Leiner T, Bogaert J, Friedrich MG, Mohiaddin R, Muthurangu V, Myerson S, Powell AJ, Raman SV, Pennell DJ. SCMR Position Paper (2020) on clinical indications for cardiovascular magnetic resonance. J CardiovasC Magn Reson. 2020. https://doi.org/10.1186/s12968-020-00682-4.

2. Messroghli DR, Moon JC, Ferreira VM, Grosse-Wortmann L, HeT, Kellman P, Mascherbauer J, Nezafat R, Salerno M, Schelbert EB, Taylor AJ, Thompson R, Ugander M, Van Heeswijk RB, Friedrich MG. Clinical recommendations for cardiovascular magnetic resonance mapping of T1, T2, T2 and extracellular volume: a consensus statement by the Society for Cardiovascular Magnetic Resonance (SCMR) endorsed by the European Association for Cardiovascular Imagin. J Cardiovasc Magn Reson. 2017. https://doi.org/10.1186/s12968-017-0389-8.

3. Von Knobelsdorff-Brenkenhoff F, Schulz-Menger J. Role of cardiovascular magnetic resonance in the guidelines of the European Society of Cardiology. J Cardiovasc Magn Reson. 2016. https://doi.org/10.1186/ s12968-016-0225-6.

4. ACCF/ACR/SCCT/SCMR/ASNC/NASCI/SCAI/SIR 2006 appropriateness criteria for cardiac computed tomography and cardiac magnetic resonance imaging. A report of the American College of Cardiology Foundation Quality Strategic Directions Committee Appropriateness C. J Am Coll Radiol. 2006. https://doi.org/10.1016/j.jacr.2006.08.008.

5. Hundley WG, Bluemke DA, Finn JP, Flamm SD, Fogel MA, Friedrich MG, Ho VB, Jerosch-Herold M, Kramer CM, Manning WJ, Patel M, Pohost GM, Stillman AE, White RD, Woodard PK. ACCF/ACR/AHA/NASCI/SCMR 2010 expert consensus document on cardiovascular magnetic resonance. A report of the American College of Cardiology Foundation Task Force on Expert Consensus Documents. J Am Coll Cardiol. 2010. https://doi.org/ 10.1016/j.jacc.2009.11.011

6. Doody MM, Freedman DM, Alexander BH, Hauptmann M, Miller JS, Rao RS, Mabuchi K, Ron E, Sigurdson AJ, Linet MS. Breast cancer incidence in US radiologic technologists. Cancer. 2006. https://doi.org/10.1002/cncr. 21876.

7. Borrego-Soto G, Ortiz-López R, Rojas-Martínez A. lonizing radiationinduced DNA injury and damage detection in patients with breast cancer. Genet Mol Biol. 2015. https://doi.org/10.1590/S1415-47573 8420150019.

8. Brent RL. Carcinogenic risks of prenatal ionizing radiation. Semin Fetal Neonatal Med. 2014. https://doi.org/10.1016/j.siny.2013.11.009.

9. Reynolds HR, Srichai MB, lqbal SN, Slater JN, Mancini GBJ, Feit F, PenaSing I, Axel L, Attubato MJ, Yatskar L, Kalhorn RT, Wood DA, Lobach IV, Hochman JS. Mechanisms of myocardial infarction in women without angiographically obstructive coronary artery disease. Circulation. 2011. https://doi.org/10.1161/CIRCULATIONAHA.111.026542.

10. Panting JR, Gatehouse PD, Yang G-Z, Grothues F, Firmin DN, Collins P, Pennell DJ. Abnormal subendocardial perfusion in cardiac syndrome $X$ detected by cardiovascular magnetic resonance imaging. N Engl J Med. 2002. https://doi.org/10.1056/nejmoa012369.

11. Pilz G, Klos M, Ali E, Hoefling B, Scheck R, Bernhardt P. Angiographic correlations of patients with small vessel disease diagnosed by adenosinestress cardiac magnetic resonance imaging. J Cardiovasc Magn Reson. 2008. https://doi.org/10.1186/1532-429X-10-8.

12. Johnson BD, Shaw LJ, Buchthal SD, Merz CNB, Kim HW, Scott KN, Doyle M, Olson MB, Pepine CJ, Den Hollander J, Sharaf B, Rogers WJ, Mankad S, Forder JR, Kelsey SF, Pohost GM. Prognosis in women with myocardial ischemia in the absence of obstructive coronary disease: Results from the National Institutes of Health-National Heart, Lung, and Blood Institute-Sponsored Women's Ischemia Syndrome Evaluation (WISE). Circulation. 2004. https://doi.org/10.1161/01.CIR.0000130642.79868.B2.

13. Nagel E, Greenwood JP, McCann GP, Bettencourt N, Shah AM, Hussain ST, Perera D, Plein S, Bucciarelli-Ducci C, Paul M, Westwood MA, Marber M, Richter W-S, Puntmann VO, Schwenke C, Schulz-Menger J, Das R, Wong J, Hausenloy DJ, Steen H, Berry C. Magnetic resonance perfusion or fractional flow reserve in coronary disease. N Engl J Med. 2019. https://doi.org/10.1056/nejmoa1716734.

14. Bucciarelli-Ducci C, Ostenfeld E, Baldassarre LA, Ferreira VM, Frank L, Kallianos K, Raman SV, Srichai MB, McAlindon E, Mavrogeni S, Ntusi NAB, Schulz-Menger J, Valente AM, Ordovas KG. Cardiovascular disease in women: insights from magnetic resonance imaging. J Cardiovasc Magn Reson. 2020;22:71. https://doi.org/10.1186/s12968-020-00666-4. 
15. Virani SS, Alonso A, Benjamin EJ, Bittencourt MS, Callaway CW, Carson AP, Chamberlain AM, Chang AR, Cheng S, Delling FN, Djousse L, Elkind MSV, Ferguson JF, Fornage M, Khan SS, Kissela BM, Knutson KL, Kwan TW, Lackland DT, Lewis TT, Lichtman JH, Longenecker CT, Loop MS, Lutsey PL, Martin SS, Matsushita K, Moran AE, Mussolino ME, Perak AM, Rosamond WD, Roth GA, Sampson UKA, Satou GM, Schroeder EB, Shah SH, Shay CM, Spartano NL, Stokes A, Tirschwell DL, VanWagner LB, Tsao CW, Wong SS, Heard DG. Heart disease and stroke statistics - 2020 update: a report from the American Heart Association. Circulation. 2020. https://doi.org/10.1161/CIR.0000000000000757.

16. Hochman JS, Tamis JE, Thompson TD, Weaver WD, White HD, Van de Werf F, Aylward P, Topol EJ, Califf RM. Sex, clinical presentation, and outcome in patients with acute coronary syndromes. Global use of strategies to open occluded coronary arteries in acute coronary syndromes Ilb investigators. N Engl J Med. 1999. https://doi.org/10.1056/NEJM1 99907223410402.

17. Poon S, Goodman SG, Yan RT, Bugiardini R, Bierman AS, Eagle KA, Johnston N, Huynh T, Grondin FR, Schenck-Gustafsson K, Yan AT. Bridging the gender gap: insights from a contemporary analysis of sex-related differences in the treatment and outcomes of patients with acute coronary syndromes. Am Heart J. 2012. https://doi.org/10.1016/j.ahj.2011.09. 025.

18. Ineid H, Fonarow GC, Cannon CP, Hernandez AF, Palacios IF, Maree AO, Wells Q, Bozkurt B, LaBresh KA, Liang L, Hong Y, Newby LK, Fletcher G, Peterson E, Wexler L. Sex differences in medical care and early death after acute myocardial infarction. Circulation. 2008. https://doi.org/10. 1161/CIRCULATIONAHA.108.789800.

19. Jónsdóttir LS, Sigfusson N, Sigvaldason H, Thorgeirsson G. Incidence and prevalence of recognised and unrecognised myocardial infarction in women. The Reykjavik Study. Eur Heart J. 1998. https://doi.org/10. 1053/euhj.1998.0980.

20. Shlipak MG, Elmouchi DA, Herrington DM, Lin F, Grady D, Hlatky MA. The incidence of unrecognized myocardial infarction in women with coronary heart disease. Ann Intern Med. 2001. https://doi.org/10.7326/ 0003-4819-134-11-200106050-00010.

21. Blomkalns AL, Chen AY, Hochman JS, Peterson ED, Trynosky K, Diercks DB, Brogan GX, Boden WE, Roe MT, Ohman EM, Gibler WB, Newby LK. Gender disparities in the diagnosis and treatment of non-ST-segment elevation acute coronary syndromes: large-scale observations from the CRUSADE (can rapid risk stratification of unstable angina patients suppress adverse outcomes with early implementation. J Am Coll Cardiol. 2005. https://doi.org/10.1016/j.jacc.2004.11.055.

22. Graham G. Acute coronary syndromes in women: recent treatment trends and outcomes. Clin Med Insights Cardiol. 2016;10:1-10. https:// doi.org/10.4137/CMC.S37145.

23. Yahagi K, Davis HR, Arbustini E, Virmani R. Sex differences in coronary artery disease: pathological observations. Atherosclerosis. 2015. https:// doi.org/10.1016/j.atherosclerosis.2015.01.017.

24. Saw J, Mancini GBJ, Humphries KH. Contemporary review on spontaneous coronary artery dissection. J Am Coll Cardiol. 2016. https://doi.org/ 10.1016/j.jacc.2016.05.034.

25. Emrich T, Emrich K, Abegunewardene N, Oberholzer K, Dueber C, Muenzel T, Kreitner KF. Cardiac MR enables diagnosis in $90 \%$ of patients with acute chest pain, elevated biomarkers and unobstructed coronary arteries. Br J Radiol. 2015. https://doi.org/10.1259/bjr.20150025.

26. Pathik B, Raman B, Amin NHM, Mahadavan D, Rajendran S, McGavigan AD, Grover S, Smith E, Mazhar J, Bridgman C, Ganesan AN, Selvanayagam JB. Troponin-positive chest pain with unobstructed coronary arteries: incremental diagnostic value of cardiovascular magnetic resonance imaging. Eur Heart J Cardiovasc Imaging. 2016. https://doi. org/10.1093/ehjci/jev289.

27. Tornvall P, Gerbaud E, Behaghel A, Chopard R, Collste O, Laraudogoitia E, Leurent G, Meneveau N, Montaudon M, Perez-David E, Sörensson P, Agewall S. Myocarditis or "true" infarction by cardiac magnetic resonance in patients with a clinical diagnosis of myocardial infarction without obstructive coronary disease: a meta-analysis of individual patient data. Atherosclerosis. 2015. https://doi.org/10.1016/j.atheroscle rosis.2015.04.816.

28. Khan JN, McCann GP. Cardiovascular magnetic resonance imaging assessment of outcomes in acute myocardial infarction. World J Cardiol. 2017. https://doi.org/10.4330/wjc.v9.i2.109.
29. Agewall S, Beltrame JF, Reynolds HR, Niessner A, Rosano G, Caforio ALP, De Caterina R, Zimarino M, Roffi M, Kjeldsen K, Atar D, Kaski JC, Sechtem U, Tornvall P. ESC working group position paper on myocardial infarction with non-obstructive coronary arteries. Eur Heart J. 2017. https:// doi.org/10.1093/eurheartj/ehw149.

30. Dastidar AG, Baritussio A, De Garate E, Drobni Z, Biglino G, Singhal P, Milano EG, Angelini GD, Dorman S, Strange J, Johnson T, BucciarelliDucci C. Prognostic role of CMR and conventional risk factors in myocardial infarction with nonobstructed coronary arteries. JACC Cardiovasc Imaging. 2019. https://doi.org/10.1016/j.jcmg.2018.12.023.

31. Pasupathy S, Air T, Dreyer RP, Tavella R, Beltrame JF. Systematic review of patients presenting with suspected myocardial infarction and nonobstructive coronary arteries. Circulation. 2015. https://doi.org/10.1161/ CIRCULATIONAHA.114.011201.

32. Ibanez B, Aletras AH, Arai AE, Arheden H, Bax J, Berry C, Bucciarelli-Ducci C, Croisille P, Dall'Armellina E, Dharmakumar R, Eitel I, Fernández-Jiménez R, Friedrich MG, García-Dorado D, Hausenloy DJ, Kim RJ, Kozerke S, Kramer CM, Salerno M, Sánchez-González J, Sanz J, Fuster V. Cardiac MRI endpoints in myocardial infarction experimental and clinical trials: JACC scientific expert panel. J Am Coll Cardiol. 2019. https://doi.org/10. 1016/j.jacc.2019.05.024.

33. Naghavi M, Abajobir AA, Abbafati C, Abbas KM, Abd-Allah F, Abera SF, Aboyans V, Adetokunboh O, Ärnlöv J, Afshin A, Agrawal A, Kiadaliri AA, Ahmadi A, Ahmed MB, Aichour AN, Aichour I, Aichour MTE, Aiyar S, Al-Eyadhy A, Alahdab F, Al-Aly Z, Alam K, Alam N, Alam T, Alene KA, Ali SD, Alizadeh-Navaei R, Alkaabi JM, Alkerwi A, Alla F, Allebeck P, Allen C, Al-Raddadi R, Alsharif U, Altirkawi KA, Alvis-Guzman N, Amare AT, Amini E, Ammar W, Amoako YA, Anber N, Andersen HH, Andrei CL, Androudi S, Ansari H, Antonio CAT, Anwari P, Arora M, Artaman A, Aryal KK, Asayesh H, Asgedom SW, Atey TM, Avila-Burgos L, Avokpaho EFGA, Awasthi A, Quintanilla BPA, Béjot Y, Babalola TK, Bacha U, Balakrishnan K, Barac A, Barboza MA, Barker-Collo SL, Barquera S, Barregard L, Barrero LH, Baune BT, Bedi N, Beghi E, Bekele BB, Bell ML, Bennett JR, Bensenor IM, Berhane A, Bernabé E, Betsu BD, Beuran M, Bhatt S, Biadgilign S, Bienhof K, Bikbov B, Bisanzio D, Bourne RRA, Breitborde NJK, Bulto LNB, Bumgarner BR, Butt ZA, Cárdenas R, Cahuana-Hurtado L, Cameron E, Campuzano JC, Car J, Carrero JJ, Carter A, Casey DC, Castañeda-Orjuela CA, Catalá-López F, Charlson FJ, Chibueze CE, Chimed-Ochir O, Chisumpa VH, Chitheer AA, Christopher DJ, Ciobanu LG, Cirillo M, Cohen AJ, Colombara D, Cooper C, Cowie BC, Criqui MH, Dandona L, Dandona R, Dargan PI, Das Neves J, Davitoiu DV, Davletov K, De Courten B, Degenhardt L, Deiparine S, Deribe K, Deribew A, Dey S, Dicker D, Ding EL, Djalalinia S, Do HP, Doku DT, Douwes-Schultz D, Driscoll TR, Dubey M, Duncan BB, Echko M, El-Khatib ZZ, Ellingsen CL, Enayati A, Erskine HE, Eskandarieh S, Esteghamati A, Ermakov SP, Estep K, Sa Farinha CS, Faro A, Farzadfar F, Feigin VL, Fereshtehnejad SM, Fernandes JC, Ferrari AJ, Feyissa TR, Filip I, Finegold S, Fischer F, Fitzmaurice C, Flaxman AD, Foigt N, Frank T, Fraser M, Fullman N, Fürst T, Furtado JM, Gakidou E, Garcia-Basteiro AL, Gebre T, Gebregergs GB, Gebrehiwot TT, Gebremichael DY, Geleijnse JM, Genova-Maleras R, Gesesew HA, Gething PW, Gillum RF, Ginawi IAM, Giref AZ, Giroud M, Giussani G, Godwin WW, Gold AL, Goldberg EM, Gona PN, Gopalani SV, Gouda HN, Goulart AC, Griswold M, Gupta PC, Gupta R, Gupta T, Gupta V, Haagsma JA, Hafezi-Nejad N, Hailu AD, Hailu GB, Hamadeh RR, Hambisa MT, Hamidi S, Hammami M, Hancock J, Handal AJ, Hankey GJ, Hao Y, Harb HL, Hareri HA, Hassanvand MS, Havmoeller R, Hay SI, He F, Hedayati MT, Henry NJ, Heredia-Pi IB, Herteliu C, Hoek HW, Horino M, Horita N, Hosgood HD, Hostiuc S, Hotez PJ, Hoy DG, Huynh C, Iburg KM, Ikeda C, lleanu BV, Irenso AA, Irvine CMS, Jürisson M, Jacobsen $\mathrm{KH}$, Jahanmehr $\mathrm{N}$, Jakovljevic MB, Javanbakht M, Jayaraman SP, Jeemon P, Jha V, John D, Johnson CO, Johnson SC, Jonas JB, Kabir Z, Kadel R, Kahsay A, Kamal R, Karch A, Karimi SM, Karimkhani C, Kasaeian A, Kassaw NA, Kassebaum NJ, Katikireddi SV, Kawakami N, Keiyoro PN, Kemmer L, Kesavachandran CN, Khader YS, Khan EA, Khang YH, Khoja ATA, Khosravi A, Khosravi MH, Khubchandani J, Kieling C, Kievlan D, Kim D, Kim YJ, Kimokoti RW, Kinfu Y, Kissoon N, Kivimaki M, Knudsen AK, Kopec JA, Kosen S, Koul PA, Koyanagi A, Defo BK, Kulikof XR, Kumar GA, Kumar P, Kutz M, Kyu HH, Lal DK, Lalloo R, Lambert TLN, Lan Q, Lansingh VC, Larsson A, Lee PH, Leigh J, Leung J, Levi M, Li Y, Kappe DL, Liang X, Liben ML, Lim SS, Liu A, Liu PY, Liu Y, Lodha R, Logroscino G, Lorkowski S, Lotufo PA, Lozano R, Lucas TCD, Ma S, Macarayan ERK, Maddison ER, Abd El Razek MM, Majdan M, 
Majdzadeh R, Majeed A, Malekzadeh R, Malhotra R, Malta DC, Manguerra H, Manyazewal T, Mapoma CC, Marczak LB, Markos D, Martinez-Raga J, Martins-Melo FR, Martopullo I, McAlinden C, McGaughey M, McGrath JJ, Mehata S, Meier T, Meles KG, Memiah P, Memish ZA, Mengesha MM, Mengistu DT, Menota BG, Mensah GA, Meretoja A, Meretoja TJ, Millear A, Miller TR, Minnig S, Mirarefn M, Mirrakhimov EM, Misganaw A, Mishra SR, Mohammad KA, Mohammadi A, Mohammed S, Mokdad AH, Mola GLD, Mollenkopf SK, Molokhia M, Monasta L, Hernandez JCM, Montico M, Mooney MD, Moradi-Lakeh M, Moraga P, Morawska L, Morrison SD, Morozof C, Mountjoy-Venning C, Mruts KB, Muller K, Murthy GVS, Musa KI, Nachega JB, Naheed A, Naldi L, Nangia V, Nascimento BR, Nasher JT, Natarajan G, Negoi I, Ngunjiri JW, Nguyen CT, Nguyen G, Nguyen M, Le Nguyen Q, Nguyen TH, Nichols E, Ningrum DNA, Nong VM, Noubiap JJN, Ogbo FA, Oh IH, Okoro A, Olagunju AT, Olsen HE, Olusanya BO, Olusanya JO, Ong K, Opio JN, Oren E, Ortiz A, Osman M, Ota E, Mahesh PA, Pacella RE, Pakhale S, Pana A, Panda BK, Jonas S, Papachristou C, Park EK, Patten SB, Patton GC, Paudel D, Paulson K, Pereira DM, Perez-Ruiz F, Perico N, Pervaiz A, Petzold M, Phillips MR, Pigott DM, Pinho C, Plass D, Pletcher MA, Polinder S, Postma MJ, Pourmalek F, Purcell C, Qorbani M, Radfar A, Rafay A, Rahimi-Movaghar V, Rahman M, Ur Rahman MH, Rai RK, Ranabhat CL, Rankin Z, Rao PC, Rath GK, Rawaf S, Ray SE, Rehm J, Reiner RC, Reitsma MB, Remuzzi G, Rezaei S, Rezai MS, Rokni MB, Ronfani L, Roshandel G, Roth GA, Rothenbacher D, Ruhago GM, Rizwan SA, Saadat S, Sachdev PS, Sadat N, Safdarian M, Saf S, Safiri S, Sagar R, Sahathevan R, Salama J, Salamati P, Salomon JA, Samy AM, Sanabria JR, Sanchez-Niño MD, Santomauro D, Santos IS, Milicevic MMS, Sartorius B, Satpathy M, Shahraz S, Schmidt MI, Schneider IJC, Schulhofer-Wohl S, Schutte AE, Schwebel DC, Schwendicke F, Sepanlou SG, Servan-Mori EE, Shackelford KA, Shaikh MA, Shamsipour M, Shamsizadeh M, Islam SMS, Sharma J, Sharma R, She J, Sheikhbahaei S, Shey M, Shi P, Shields C, Shigematsu M, Shiri R, Shirude S, Shiue I, Shoman H, Shrime MG, Sigfusdottir ID, Silpakit N, Silva JP, Singh A, Singh JA, Skiadaresi E, Sligar A, Smith A, Smith DL, Smith M, Sobaih BHA, Soneji S, Sorensen RJD, Soriano JB, Sreeramareddy CT, Srinivasan V, Stanaway JD, Stathopoulou V, Steel N, Stein DJ, Steiner C, Steinke S, Stokes MA, Strong M, Strub B, Subart M, Sufyan MB, Sunguya BF, Sur PJ, Swaminathan S, Sykes BL, Tabarés-Seisdedos R, Tadakamadla SK, Takahashi K, Takala JS, Talongwa RT, Tarawneh MR, Tavakkoli M, Taveira N, Tegegne TK, Tehrani-Banihashemi A, Temsah MH, Terkawi AS, Thakur JS, Thamsuwan O, Thankappan KR, Thomas KE, Thompson AH, Thomson AJ, Thrift AG, Tobe-Gai R, Topor-Madry R, Torre A, Tortajada M, Towbin JA, Tran BX, Troeger C, Truelsen T, Tsoi D, Tuzcu EM, Tyrovolas S, Ukwaja KN, Undurraga EA, Updike R, Uthman OA, Uzochukwu BSC, Van Boven JFM, Vasankari T, Venketasubramanian N, Violante FS, Vlassov VV, Vollset SE, Vos T, Wakayo T, Wallin MT, Wang YP, Weiderpass E, Weintraub RG, Weiss DJ, Werdecker A, Westerman R, Whetter B, Whiteford HA, Wijeratne T, Wiysonge CS, Woldeyes BG, Wolfe CDA, Woodbrook R, Workicho A, Xavier D, Xiao Q, Xu G, Yaghoubi M, Yakob B, Yano Y, Yaseri M, Yimam HH, Yonemoto N, Yoon SJ, Yotebieng M, Younis MZ, Zaidi Z, El Sayed Zaki M, Zegeye EA, Zenebe ZM, Zerfu TA, Zhang AL, Zhang X, Zipkin B, Zodpey S, Lopez AD, Murray CJL. Global, regional, and national age-sex specifc mortality for 264 causes of death, 1980-2016: a systematic analysis for the Global Burden of Disease Study 2016. Lancet. 2017. https://doi.org/10.1016/S0140-6736(17)32152-9.

34. Roth GA, Johnson C, Abajobir A, Abd-Allah F, Abera SF, Abyu G, Ahmed M, Aksut B, Alam T, Alam K, Alla F, Alvis-Guzman N, Amrock S, Ansari $\mathrm{H}$, Ärnlöv J, Asayesh H, Atey TM, Avila-Burgos L, Awasthi A, Banerjee A, Barac A, Bärnighausen T, Barregard L, Bedi N, Belay Ketema E, Bennett D, Berhe G, Bhutta Z, Bitew S, Carapetis J, Carrero JJ, Malta DC, CastañedaOrjuela CA, Castillo-Rivas J, Catalá-López F, Choi JY, Christensen H, Cirillo M, Cooper L, Criqui M, Cundiff D, Damasceno A, Dandona L, Dandona R, Davletov K, Dharmaratne S, Dorairaj P, Dubey M, Ehrenkranz R, El Sayed Zaki M, Faraon EJA, Esteghamati A, Farid T, Farvid M, Feigin V, Ding EL, Fowkes G, Gebrehiwot T, Gillum R, Gold A, Gona P, Gupta R, Habtewold TD, Hafezi-Nejad N, Hailu T, Hailu GB, Hankey G, Hassen HY, Abate KH, Havmoeller R, Hay SI, Horino M, Hotez PJ, Jacobsen K, James S, Javanbakht M, Jeemon P, John D, Jonas J, Kalkonde Y, Karimkhani C, Kasaeian A, Khader Y, Khan A, Khang YH, Khera S, Khoja AT, Khubchandani J, Kim D, Kolte D, Kosen S, Krohn KJ, Kumar GA, Kwan GF, Lal DK, Larsson A, Linn S, Lopez A, Lotufo PA, El Razek HMA, Malekzadeh R, Mazidi M, Meier T, Meles KG, Mensah G, Meretoja A, Mezgebe H, Miller
T, Mirrakhimov E, Mohammed S, Moran AE, Musa KI, Narula J, Neal B, Ngalesoni F, Nguyen G, Obermeyer CM, Owolabi M, Patton G, Pedro J, Qato D, Qorbani M, Rahimi K, Rai RK, Rawaf S, Ribeiro A, Safiri S, Salomon JA, Santos I, Santric Milicevic M, Sartorius B, Schutte A, Sepanlou S, Shaikh MA, Shin MJ, Shishehbor M, Shore H, Silva DAS, Sobngwi E, Stranges S, Swaminathan S, Tabarés-Seisdedos R, Tadele Atnafu N, Tesfay F, Thakur JS, Thrift A, Topor-Madry R, Truelsen T, Tyrovolas S, Ukwaja KN, Uthman O, Vasankari T, Vlassov V, Vollset SE, Wakayo T, Watkins D, Weintraub R, Werdecker A, Westerman R, Wiysonge CS, Wolfe C, Workicho A, Xu G, Yano Y, Yip P, Yonemoto N, Younis M, Yu C, Vos T, Naghavi M, Murray C. Global, regional, and national burden of cardiovascular diseases for 10 causes, 1990 to 2015. J Am Coll Cardiol. 2017. https:// doi.org/10.1016/j.jacc.2017.04.052.

35. Fihn SD, Gardin JM, Abrams J, Berra K, Blankenship JC, Dallas AP, Douglas PS, Foody JM, Gerber TC, Hinderliter AL, King SB, Kligfield PD, Krumholz HM, Kwong RYK, Lim MJ, Linderbaum JA, MacK MJ, Munger MA, Prager RL, Sabik JF, Shaw LJ, Sikkema JD, Smith CR, Smith SC, Spertus JA, Williams SV. 2012 ACCF/AHA/ACP/AATS/PCNA/SCAI/STS guideline for the diagnosis and management of patients with stable ischemic heart disease. J Am Coll Cardiol. 2012. https://doi.org/10.1016/j.jacc.2012.07. 013.

36. Pepine CJ, Ferdinand KC, Shaw LJ, Light-McGroary KA, Shah RU, Gulati M, Duvernoy C, Walsh MN, Merz CNB. Emergence of nonobstructive coronary artery disease: a woman's problem and need for change in definition on angiography. J Am Coll Cardiol. 2015. https://doi.org/10. 1016/j.jacc.2015.08.876.

37. Merz CNB, Shaw LJ, Reis SE, Bittner V, Kelsey SF, Olson M, Johnson BD, Pepine CJ, Mankad S, Sharaf BL, Rogers WJ, Pohost GM, Lerman A, Quyyumi AA, Sopko G. Insights from the NHLBI-sponsored Women's Ischemia Syndrome Evaluation (WISE) study Part II: Gender differences in presentation, diagnosis, and outcome with regard to gender-based pathophysiology of atherosclerosis and macrovascular and microvascular cor. J Am Coll Cardiol. 2006. https://doi.org/10.1016/j.jacc.2004.12. 084.

38. Heller G, Babitsch B, Günster C, Möckel M. Mortality following myocardial infarction in women and men: an analysis of insurance claims data from inpatient hospitalizations. Deutsches Ärzteblatt Int. 2008. https:// doi.org/10.3238/arztebl.2008.0279.

39. Konstantino Y, Chen E, Hasdai D, Boyko V, Battler A, Behar S, Haim M. Gender differences in mortality after acute myocardial infarction with mild to moderate heart failure. Acute Card Care. 2007. https://doi.org/ 10.1080/17482940601100819.

40. Baldassarre LA, Raman SV, Min JK, Mieres JH, Gulati M, Wenger NK, Marwick TH, Bucciarelli-Ducci C, Merz CNB, Itchhaporia D, Ferdinand KC, Pepine CJ, Walsh MN, Narula J, Shaw LJ. Noninvasive imaging to evaluate women with stable ischemic heart disease. JACC Cardiovasc Imaging. 2016. https://doi.org/10.1016/j.jcmg.2016.01.004.

41. Wolk MJ, Bailey SR, Doherty JU, Douglas PS, Hendel RC, Kramer CM, Min JK, Patel MR, Rosenbaum L, Shaw LJ, Stainback RF, Allen JM, Brindis RG, Cerqueira MD, Chen J, Dean LS, Fazel R, Hundley WG, Itchhaporia D, Kligfield P, Lockwood R, Marine JE, McCully RB, Messer JV, O'Gara PT, Shemin RJ, Wann LS, Wong JB, Brown AS, Lindsay BD. ACCF/AHA/ASE/ ASNC/HFSA/HRS/SCAI/SCCT/SCMR/STS 2013 multimodality appropriate use criteria for the detection and risk assessment of stable ischemic heart disease. J Cardiac Fail. 2014. https://doi.org/10.1016/j.cardfail. 2013.12.002.

42. Fihn SD, Blankenship JC, Alexander KP, Bittl JA, Byrne JG, Fletcher BJ, Fonarow GC, Lange RA, Levine GN, Maddox TM, Naidu SS, Ohman EM, Smith PK. 2014 ACC/AHA/AATS/PCNA/SCAI/STS focused update of the guideline for the diagnosis and management of patients with stable ischemic heart disease. J Am Coll Cardiol. 2014. https://doi.org/10. 1016/j.jacc.2014.07.017.

43. Mieres JH, Gulati M, Merz NB, Berman DS, Gerber TC, Hayes SN, Kramer CM, Min JK, Newby LK, Nixon JV, Srichai MB, Pellikka PA, Redberg RF, Wenger NK, Shaw $\sqcup$. Role of noninvasive testing in the clinical evaluation of women with suspected ischemic heart disease: a consensus statement from the american heart association. Circulation. 2014. https://doi.org/10.1161/CIR.0000000000000061.

44. Knuuti J. 2019 ESC Guidelines for the diagnosis and management of chronic coronary syndromes. The Task Force for the diagnosis and management of chronic coronary syndromes of the European Society 
of Cardiology (ESC). Russ J Cardiol. 2020. https://doi.org/10.15829/ 1560-4071-2020-2-3757.

45. Greenwood JP, Motwani M, Maredia N, Brown JM, Everett CC, Nixon J, Bijsterveld P, Dickinson CJ, Ball SG, Plein S. Comparison of cardiovascular magnetic resonance and single-photon emission computed tomography in women with suspected coronary artery disease from the clinical evaluation of magnetic resonance imaging in coronary heart disease (CE-MARC) trial. Circulation. 2014. https://doi.org/10.1161/CIRCULATIO NAHA.112.000071.

46. Patel MB, Bui LP, Kirkeeide RL, Gould KL. Imaging microvascular dysfunction and mechanisms for female-male differences in CAD. JACC Cardiovasc Imaging. 2016. https://doi.org/10.1016/j.jcmg.2016.02.003.

47. Engblom H, Xue H, Akil S, Carlsson M, Hindorf C, Oddstig J, Hedeer F, Hansen MS, Aletras AH, Kellman P, Arheden H. Fully quantitative cardiovascular magnetic resonance myocardial perfusion ready for clinical use: a comparison between cardiovascular magnetic resonance imaging and positron emission tomography. J Cardiovasc Magn Reson. 2017. https://doi.org/10.1186/s12968-017-0388-9.

48. Wei J, Bakir M, Darounian N, Li Q, Landes S, Mehta PK, Shufelt CL, Handberg EM, Kelsey SF, Sopko G, Pepine CJ, Petersen JW, Berman DS, Thomson LEJ, Merz CNB. Myocardial scar is prevalent and associated with subclinical myocardial dysfunction in women with suspected ischemia but no obstructive coronary artery disease: from the women's ischemia syndrome evaluation-coronary vascular dysfunction study. Circulation. 2018. https://doi.org/10.1161/CIRCULATIONAHA.117.031999.

49. Dastidar AG, Rodrigues JCL, Ahmed N, Baritussio A, Bucciarelli-Ducci C. The role of cardiac MRI in patients with troponin-positive chest pain and unobstructed coronary arteries. Curr Cardiovasc Imaging Rep. 2015. https://doi.org/10.1007/s12410-015-9345-x.

50. Gulati M, Shaw L, Merz CNB. Myocardial ischemia in women: lessons from the NHLBI WISE study. Clin Cardiol. 2012. https://doi.org/10.1002/ clc.21966

51. Raman SV, Dickerson JA, Mazur W, Wong TC, Schelbert EB, Min JK, Scandling D, Bartone C, Craft JT, Thavendiranathan P, Mazzaferri EL, Arnold JW, Gilkeson R, Simonetti OP. Diagnostic performance of treadmill exercise cardiac magnetic resonance: the prospective, multicenter exercise CMR's accuracy for cardiovascular stress testing (EXACT) trial. J Am Heart Assoc. 2016. https://doi.org/10.1161/JAHA.116.003811.

52. Kramer CM, Barkhausen J, Flamm SD, Kim RJ, Nagel E. Standardized cardiovascular magnetic resonance imaging (CMR) protocols, society for cardiovascular magnetic resonance: board of trustees task force on standardized protocols. J Cardiovasc Magn Reson. 2008. https://doi.org/ 10.1186/1532-429X-10-35.

53. Piechnik SK, Neubauer S, Ferreira VM. State-of-the-art review: stress T1 mapping - technical considerations, pitfalls and emerging clinical applications. Magn Resonance Mater Phys Biol Med. 2018. https://doi. org/10.1007/s10334-017-0649-5.

54. Nakamori S, Fahmy A, Jang J, El-Rewaidy H, Neisius U, Berg S, Goddu B, Pierce P, Rodriguez J, Hauser T, Ngo LH, Manning WJ, Nezafat R. Changes in myocardial native $\mathrm{T} 1$ and $\mathrm{T} 2$ after exercise stress: a noncontrast CMR pilot study. JACC Cardiovasc Imaging. 2020. https://doi.org/10.1016/j. jcmg.2019.05.019.

55. Haghikia A, Röntgen P, Vogel-Claussen J, Hilfiker-Kleiner D, Bauersachs J. Characterization of peripartum cardiomyopathy by cardiovascular magnetic resonance imaging. J Cardiovasc Magn Reson. 2015. https:// doi.org/10.1186/1532-429x-17-s1-q46.

56. Johnson-Coyle L, Jensen L, Sobey A. Peripartum cardiomyopathy: review and practice guidelines. Am J Crit Care. 2012. https://doi.org/10. 4037/ajcc2012163.

57. Demakis JG, Rahimtoola SH, Sutton GC, Meadows WR, Szanto PB, Tobin $J R$, Gunnar RM. Natural course of peripartum cardiomyopathy. Circulation. 1971. https://doi.org/10.1161/01.CIR.44.6.1053.

58. Al-Lamee R, Thompson D, Dehbi HM, Sen S, Tang K, Davies J, Keeble T, Mielewczik M, Kaprielian R, Malik IS, Nijjer SS, Petraco R, Cook C, Ahmad Y, Howard J, Baker C, Sharp A, Gerber R, Talwar S, Assomull R, Mayet J, Wensel R, Collier D, Shun-Shin M, Thom SA, Davies JE, Francis DP, Al-Lamee R, Thompson D, Sen S, Tang K, Davies J, Keeble T, Kaprielian R, Malik IS, Nijjer SS, Petraco R, Cook C, Ahmad Y, Howard J, Shun-Shin M, Sethi A, Baker C, Sharp A, Ramrakha P, Gerber R, Talwar S, Assomull R, Foale R, Mayet J, Wensel R, Thom SA, Davies JE, Francis DP, Khamis R, Hadjiloizou N, Khan M, Kooner J, Bellamy M, Mikhail G, Clifford P, O'Kane
P, Levy T, Swallow R. Percutaneous coronary intervention in stable angina (ORBITA): a double-blind, randomised controlled trial. Lancet. 2018. https://doi.org/10.1016/S0140-6736(17)32714-9.

59. Brar SS, Khan SS, Sandhu GK, Jorgensen MB, Parikh N, Hsu JWY, Shen AYJ. Incidence, mortality, and racial differences in peripartum cardiomyopathy. Am J Cardiol. 2007. https://doi.org/10.1016/j.amjcard.2007. 02.092.

60. Mouquet F, Lions C, Groote P, Bouabdallaoui N, Willoteaux S, Dagorn J, Deruelle P, Lamblin N, Bauters C, Beregi JP. Characterisation of peripartum cardiomyopathy by cardiac magnetic resonance imaging. Eur Radiol. 2008. https://doi.org/10.1007/s00330-008-1067-x.

61. Marmursztejn J, Vignaux O, Goffinet F, Cabanes L, Duboc D. Delayedenhanced cardiac magnetic resonance imaging features in peripartum cardiomyopathy. Int J Cardiol. 2009. https://doi.org/10.1016/j.ijcard. 2009.04.028.

62. Arora NP, Mohamad T, Mahajan N, Danrad R, Kottam A, Li T, Afonso LC. Cardiac magnetic resonance imaging in peripartum cardiomyopathy. Am J Med Sci. 2014. https://doi.org/10.1097/MAJ.0b013e31828155e3.

63. Ferreira VM, Schulz-Menger J, Holmvang G, Kramer CM, Carbone I, Sechtem U, Kindermann I, Gutberlet M, Cooper LT, Liu P, Friedrich MG. Cardiovascular magnetic resonance in nonischemic myocardial inflammation: expert recommendations. J Am Coll Cardiol. 2018. https://doi. org/10.1016/j.jacc.2018.09.072.

64. Anonymous, cancer facts and figures 2013, American Cancer Society. 2013.

65. Bowles EJA, Wellman R, Feigelson HS, Onitilo AA, Freedman AN, Delate T, Allen LA, Nekhlyudov L, Goddard KAB, Davis RL, Habel LA, Yood MU, McCarty C, Magid DJ, Wagner EH. Risk of heart failure in breast cancer patients after anthracycline and trastuzumab treatment: a retrospective cohort study. J Natl Cancer Inst. 2012. https://doi.org/10.1093/jnci/ djs317.

66. Patnaik JL, Byers T, DiGuiseppi C, Dabelea D, Denberg TD. Cardiovascular disease competes with breast cancer as the leading cause of death for older females diagnosed with breast cancer: a retrospective cohort study. Breast Cancer Res. 2011. https://doi.org/10.1186/bcr2901.

67. Kim HI, Lim H, Moon A. Sex differences in cancer: epidemiology, genetics and therapy. Biomol Therap. 2018. https://doi.org/10.4062/biomo Ither.2018.103.

68. Zamorano IL, Anastasakis A, Borger MA, Borggrefe M, Cecchi F, Charron P, Hagege AA, Lafont A, Limongelli G, Mahrholdt H, McKenna WJ, Mogensen J, Nihoyannopoulos P, Nistri S, Piepe PG, Pieske B, Rapezzi C, Rutten FH, Tillmanns C, Watkins H, O'Mahony C, Achenbach S, Baumgartner H, Bax JJ, Bueno H, Dean V, Deaton C, Erol Ç, Fagard R, Ferrari R, Hasdai D, Hoes AW, Kirchhof P, Knuuti J, Kolh P, Lancellotti P, Linhart A, Piepoli MF, Ponikowski P, Sirnes PA, Tamargo JL, Tendera M, Torbicki A, Wijns W, Windecker S, Alfonso F, Basso C, Cardim NM, Gimeno JR, Heymans S, Holm PJ, Keren A, Lionis C, Muneretto C, Priori S, Salvador MJ, Wolpert C. 2014 ESC guidelines on diagnosis and management of hypertrophic cardiomyopathy: the task force for the diagnosis and management of hypertrophic cardiomyopathy of the European Society of Cardiology (ESC). Eur Heart J. 2014. https://doi.org/10.1093/eurhe artj/ehu284.

69. Plana JC, Galderisi M, Barac A, Ewer MS, Ky B, Scherrer-Crosbie M, Ganame J, Sebag IA, Agler DA, Badano LP, Banchs J, Cardinale D, Carver J, Cerqueira M, DeCara JM, Edvardsen T, Flamm SD, Force T, Griffin BP, Jerusalem G, Liu JE, Magalhães A, MarwickT, Sanchez LY, Sicari R, Villarraga HR, Lancellotti P. Expert consensus for multimodality imaging evaluation of adult patients during and after cancer therapy: a report from the American Society of Echocardiography and the European Association of Cardiovascular Imaging. Eur Heart J Cardiovasc Imaging. 2014. https://doi.org/10.1093/ehjci/jeu192.

70. Mackey JR, Clemons M, Côté MA, Delgado D, Dent S, Paterson A, Provencher L, Sawyer MB, Verma S. Cardiac management during adjuvant trastuzumab therapy: recommendations of the Canadian Trastuzumab Working Group. Curr Oncol. 2008. https://doi.org/10.3747/ co.2008.199.

71. Armstrong GT, Plana JC, Zhang N, Srivastava D, Green DM, Ness KK, Donovan FD, Metzger ML, Arevalo A, Durand JB, Joshi V, Hudson MM, Robison LL, Flamm SD. Screening adult survivors of childhood cancer for cardiomyopathy: comparison of echocardiography and cardiac 
magnetic resonance imaging. J Clin Oncol. 2012. https://doi.org/10. 1200/JCO.2011.40.3584.

72. Thavendiranathan P, Grant AD, Negishi T, Plana JC, Popović ZB, Marwick TH. Reproducibility of echocardiographic techniques for sequential assessment of left ventricular ejection fraction and volumes: application to patients undergoing cancer chemotherapy. J Am Coll Cardiol. 2013. https://doi.org/10.1016/j.jacc.2012.09.035.

73. Walker J, Bhullar N, Fallah-Rad N, Lytwyn M, Golian M, Fang T, Summers AR, Singal PK, Barac I, Kirkpatrick ID, Jassal DS. Role of three-dimensional echocardiography in breast cancer: comparison with two-dimensional echocardiography, multiple-gated acquisition scans, and cardiac magnetic resonance imaging. J Clin Oncol. 2010. https://doi.org/10.1200/ JCO.2009.26.7294.

74. Kramer CM, Barkhausen J, Bucciarelli-Ducci C, Flamm SD, Kim RJ, Nagel E. Standardized cardiovascular magnetic resonance imaging (CMR) protocols: 2020 update. J Cardiovasc Magn Reson. 2020. https://doi. org/10.1186/s12968-020-00607-1.

75. Fallah-Rad N, Lytwyn M, Fang T, Kirkpatrick I, Jassal DS. Delayed contrast enhancement cardiac magnetic resonance imaging in trastuzumab induced cardiomyopathy. J Cardiovasc Magn Reson. 2008. https://doi. org/10.1186/1532-429X-10-5.

76. Drafts BC, Twomley KM, D'Agostino R, Lawrence J, Avis N, Ellis LR, Thohan V, Jordan J, Melin SA, Torti FM, Little WC, Hamilton CA, Hundley WG. Low to moderate dose anthracycline-based chemotherapy is associated with early noninvasive imaging evidence of subclinical cardiovascular disease. JACC Cardiovasc Imaging. 2013. https://doi.org/ 10.1016/j.jcmg.2012.11.017.

77. Grover S, DePasquale C, Leong DP, Chakrabarty A, Cheong KA, Kotasek D, Joshi R, Penhall A, Jeorg L, Joseph M, Koczwara B, Selvanayagam J. Early cardiac changes following anthracycline chemotherapy in breast cancer: a prospective multi-centre study using advanced cardiac imaging and biochemical markers. J Cardiovasc Magn Reson. 2012. https:// doi.org/10.1186/1532-429x-14-s1-p181.

78. Grover S, DePasquale C, Srinivasan G, Leong DP, Chakrabarty A, Cheong KA, Joshi R, Penhall A, Joseph M, Koczwara B, Selvanayagam J. Early and late left ventricular effects of breast cancer chemotherapy: a prospective multi-centre study using advanced cardiac imaging. J Cardiovasc Magn Reson. 2013. https://doi.org/10.1186/1532-429x-15-s1-p142.

79. Tham EB, Haykowsky MJ, Chow K, Spavor M, Kaneko S, Khoo NS, Pagano JJ, Mackie AS, Thompson RB. Diffuse myocardial fibrosis by T1-mapping in children with subclinical anthracycline cardiotoxicity: relationship to exercise capacity, cumulative dose and remodeling. J Cardiovasc Magn Reson. 2013. https://doi.org/10.1186/1532-429X-15-48.

80. Jordan JH, Vasu S, Morgan TM, D'Agostino RB, Meléndez GC, Hamilton CA, Arai AE, Liu S, Liu CY, Lima JAC, Bluemke DA, Burke GL, Hundley WG. Anthracycline-associated T1 mapping characteristics are elevated independent of the presence of cardiovascular comorbidities in cancer survivors. Circulation Cardiovasc Imaging. 2016. https://doi.org/10. 1161/CIRCIMAGING.115.004325.

81. Siu SC, Silversides CK. Bicuspid aortic valve disease. J Am Coll Cardiol. 2010. https://doi.org/10.1016/j.jacc.2009.12.068.

82. Booher AM, Eagle KA. Diagnosis and management issues in thoracic aortic aneurysm. Am Heart J. 2011. https://doi.org/10.1016/j.ahj.2011. 04.010.

83. Fedak PWM, De Sa MPL, Verma S, Nili N, Kazemian P, Butany J, Strauss BH, Weisel RD, David TE, Yacoub MH, Sundt TM, Sellke FW, Pizarro C. Vascular matrix remodeling in patients with bicuspid aortic valve malformations: implications for aortic dilatation. J Thorac Cardiovasc Surg. 2003. https://doi.org/10.1016/50022-5223(03)00398-2.

84. Warnes CA, Williams RG, Bashore TM, Child JS, Connolly HM, Dearani JA, del Nido P, Fasules JW, Graham TP, Hijazi ZM, Hunt SA, King ME, Landzberg MJ, Miner PD, Radford MJ, Walsh EP, Webb GD. ACC/AHA 2008 guidelines for the management of adults with congenital heart disease. J Am Coll Cardiol. 2008. https://doi.org/10.1016/j.jacc.2008.10.002

85. Nishimura RA, Otto CM, Bonow RO, Carabello BA, Erwin JP, Guyton RA, O'Gara PT, Ruiz CE, Skubas NJ, Sorajja P, Sundt TM, Thomas JD. 2014 AHA/ACC guideline for the management of patients with valvular heart disease: a report of the American college of cardiology/American heart association task force on practice guidelines. J Am Coll Cardiol. 2014. https://doi.org/10.1016/j.jacc.2014.02.536.
86. Kong WKF, Regeer MV, Ng ACT, McCormack L, Poh KK, Yeo TC, Shanks $M$, Parent S, Enache R, Popescu BA, Yip JW, Ma L, Kamperidis V, van der Velde ET, Mertens B, Marsan NA, Delgado V, Bax JJ. Sex differences in phenotypes of bicuspid aortic valve and aortopathy. Circ Cardiovasc Imaging. 2017. https://doi.org/10.1161/circimaging.116.005155.

87. Michelena HI, Suri RM, Katan O, Eleid MF, Clavel MA, Maurer MJ, Pellikka PA, Mahoney D, Enriquez-Sarano M. Sex differences and survival in adults with bicuspid aortic valves: verification in 3 contemporary echocardiographic cohorts. J Am Heart Assoc. 2016. https://doi.org/10.1161/ JAHA.116.004211.

88. Silversides CK, Colman JM, Sermer M, Farine D, Siu SC. Early and intermediate-term outcomes of pregnancy with congenital aortic stenosis. Am J Cardiol. 2003. https://doi.org/10.1016/S0002-9149(03)00340-0.

89. Chan KL, Stinson WA, Veinot JP. Reliability of transthoracic echocardiography in the assessment of aortic valve morphology: pathological correlation in 178 patients. Can J Cardiol. 1999.

90. Of M, Aortic T, In D. Guidelines for the diagnosis and management of patients with thoracic aortic disease have been released. PharmacoEcon Outcomes News. 2010.

91. Khan KS, Wojdyla D, Say L, Gülmezoglu AM, Van Look PF. WHO analysis of causes of maternal death: a systematic review. Lancet. 2006. https:// doi.org/10.1016/S0140-6736(06)68397-9.

92. Wu D, Shen YH, Russell L, Coselli JS, Lemaire SA. Molecular mechanisms of thoracic aortic dissection. J Surg Res. 2013. https://doi.org/10.1016/j. jss.2013.06.007.

93. Kamel H, Roman MJ, Pitcher A, Devereux RB. Pregnancy and the risk of aortic dissection or rupture: a cohort-crossover analysis. Circulation. 2016. https://doi.org/10.1161/CIRCULATIONAHA.116.021594.

94. Elkayam U, Ostrzega E, Shotan A, Mehra A. Cardiovascular problems in pregnant women with the Marfan syndrome. Ann Intern Med. 1995. https://doi.org/10.7326/0003-4819-123-2-199507150-00007.

95. Donnelly RT, Pinto NM, Kocolas I, Yetman AT. The immediate and long-term impact of pregnancy on aortic growth rate and mortality in women with Marfan syndrome. J Am Coll Cardiol. 2012. https://doi.org/ 10.1016/j.jacc.2012.03.051.

96. Elkayam U, Goland S, Pieper PG, Silverside CK. High-risk cardiac disease in pregnancy: part I. J Am Coll Cardiol. 2016. https://doi.org/10.1016/j. jacc.2016.05.048.

97. Stout KK, Daniels CJ, Aboulhosn JA, Bozkurt B, Broberg CS, Colman JM, Crumb SR, Dearani JA, Fuller S, Gurvitz M, Khairy P, Landzberg MJ, Saidi A, Valente AM, Van Hare GF. 2018 AHA/ACC guideline for the management of adults with congenital heart disease. J Am Coll Cardiol. 2019. https://doi.org/10.1016/j.jacc.2018.08.1029.

98. Ntusi NAB, Samuels P, Moosa S, Mocumbi AO. Diagnosing cardiac disease during pregnancy: imaging modalities. Cardiovasc J Afr. 2016. https://doi.org/10.5830/CVJA-2016-022.

99. Jimenez-Juan L, Krieger EV, Valente AM, Geva T, Wintersperger BJ, Moshonov H, Siu SC, Colman JM, Silversides CK, Wald RM. Cardiovascular magnetic resonance imaging predictors of pregnancy outcomes in women with coarctation of the aorta. Eur Heart J Cardiovasc Imaging. 2014. https://doi.org/10.1093/ehjci/jet161.

100. Balci A, Sollie-Szarynska KM, Van Der Bijl AGL, Ruys TPE, Mulder BJM, Roos-Hesselink JW, Van Dijk APJ, Wajon EMCJ, Vliegen HW, Drenthen W, Hillege HL, Aarnoudse JG, Van Veldhuisen DJ, Pieper PG. Prospective validation and assessment of cardiovascular and offspring risk models for pregnant women with congenital heart disease. Heart. 2014. https://doi.org/10.1136/heartjnl-2014-305597.

101. Silversides CK, Grewal J, Mason J, Sermer M, Kiess M, Rychel V, Wald RM, Colman JM, Siu SC. Pregnancy outcomes in women with heart disease: the CARPREG II study. J Am Coll Cardiol. 2018. https://doi.org/10.1016/j. jacc.2018.02.076.

102. Regitz-Zagrosek V, Roos-Hesselink JW, Bauersachs J, BlomströmLundqvist C, Cífková R, De Bonis M, lung B, Johnson MR, Kintscher U, Kranke P, Lang IM, Morais J, Pieper PG, Presbitero P, Price S, Rosano GMC Seeland U, Simoncini T, Swan L, Warnes CA, Windecker S, Aboyans V, Agewall S, Barbato E, Bueno H, Coca A, Collet JP, Coman IM, Dean V, Delgado V, Fitzsimons D, Gaemperli O, Hindricks G, Jüni P, Katus HA, Knuuti J, Lancellotti P, Leclercq C, McDonagh TA, Piepoli MF, Ponikowski P, Richter DJ, Roffi M, Shlyakhto E, Simpson IA, Sousa-Uva M, Zamorano $J$ L, Hammoudi N, Piruzyan A, Mascherbauer J, Samadov F, Prystrom A, Pasquet A, Caluk J, Gotcheva N, Skoric B, Heracleous H, Vejlstrup N, 
Maser M, Kaaja RJ, Srbinovska-Kostovska E, Mounier-Vehier C, Vakhtangadze T, Rybak K, Giannakoulas G, Kiss RG, Thrainsdottir IS, Erwin RJ, Porter A, Geraci G, Ibrahimi P, Lunegova O, Mintale I, Kadri Z, Benlamin H, Barysiene J, Banu CA, Caruana M, Gratii C, Haddour L, Bouma BJ, Estensen ME, Hoffman P, Petris AO, Moiseeva O, Bertelli L, Tesic BV, Dubrava J, Koželj M, Prieto-Arévalo R, Furenäs E, Schwerzmann M, Mourali MS, Ozer N, Mitchenko O, Nelson-Piercy C. 2018 ESC guidelines for the management of cardiovascular diseases during pregnancy. Eur Heart J. 2018. https://doi.org/10.1093/eurheartj/ehy340.

103. Herrey AS, Francis JM, Hughes M, Ntusi NAB. Cardiovascular magnetic resonance can be undertaken in pregnancy and guide clinical decisionmaking in this patient population. Eur Heart J Cardiovasc Imaging. 2019. https://doi.org/10.1093/ehjci/jey162.

104. Pohl D, Benseler S. Systemic inflammatory and autoimmune disorders. Handb Clin Neurol. 2013. https://doi.org/10.1016/B978-0-444-52910-7. 00047-7.

105. Aviña-Zubieta JA, Choi HK, Sadatsafavi M, Etminan M, Esdaile JM, Lacaille D. Risk of cardiovascular mortality in patients with rheumatoid arthritis: a meta-analysis of observational studies. Arthritis Care Res. 2008. https://doi.org/10.1002/art.24092.

106. Sherer Y, Shoenfeld Y. Mechanisms of disease: atherosclerosis in autoimmune diseases. Nat Clin Pract Rheumatol. 2006. https://doi.org/10. 1038/ncprheum0092.

107. Kitas GD, Gabrie SE. Cardiovascular disease in rheumatoid arthritis: state of the art and future perspectives. Ann Rheum Dis. 2011. https://doi. org/10.1136/ard.2010.142133.

108. Hollan I, Meroni PL, Ahearn JM, Cohen Tervaert JW, Curran S, Goodyear CS, Hestad KA, Kahaleh B, Riggio M, Shields K, Wasko MC. Cardiovascular disease in autoimmune rheumatic diseases. Autoimmun Rev. 2013. https://doi.org/10.1016/j.autrev.2013.03.013.

109. Björnådal L, Yin L, Granath F, Klareskog L, Ekbom A. Cardiovascular disease a hazard despite improved prognosis in patients with systemic lupus erythematosus: results from a swedish population based study 1964-95. J Rheumatol. 2004.

110. Symmons DPM, Gabriel SE. Epidemiology of CVD in rheumatic disease, with a focus on RA and SLE. Nat Rev Rheumatol. 2011. https://doi.org/ 10.1038/nrrheum.2011.75.

111. Mavrogeni S, Manoussakis MN. Myocarditis and subclavian stenosis in Takayasu arteritis. Int J Cardiol. 2011. https://doi.org/10.1016/j.ijcard. 2009.05.008.

112. Mavrogeni S, Sfikakis PP, Karabela G, Stavropoulos E, Spiliotis G, Gialafos E, Panopoulos S, Bournia V, Manolopoulou D, Kolovou G, Kitas G. Cardiovascular magnetic resonance imaging in asymptomatic patients with connective tissue disease and recent onset left bundle branch block. Int J Cardiol. 2014. https://doi.org/10.1016/j.ijcard.2013.11.059.

113. Mavrogeni S, Spargias K, Markussis V, Kolovou G, Demerouti E, Papadopoulou E, Stavridis G, Kaklamanis L, Douskou M, Constantoulakis P, Cokkinos DV. Myocardial inflammation in autoimmune diseases: investigation by cardiovascular magnetic resonance and endomyocardial biopsy. Inflamm Allergy Drug Targets. 2009. https://doi.org/10.2174/ 1871528110908050390.

114. Mavrogeni S, Bratis K, Sfendouraki E, Papadopoulou E, Kolovou G. Myopericarditis, as the first sign of rheumatoid arthritis relapse, evaluated by cardiac magnetic resonance. Inflamm Allergy Drug Targets. 2013. https://doi.org/10.2174/1871528111312030008.

115. Mavrogeni S, Sfikakis PP, Gialafos E, Karabela G, Stavropoulos E, Sfendouraki E, Panopoulos S, Kolovou G, Kitas GD. Diffuse, subendocardial vasculitis. A new entity identified by cardiovascular magnetic resonance and its clinical implications. Int J Cardiol. 2013. https://doi. org/10.1016/j.ijcard.2013.04.116

116. Raman SV, Aneja A, Jarjour WN. CMR in inflammatory vasculitis. J Cardiovasc Magn Reson. 2012. https://doi.org/10.1186/1532-429X-14-82.

117. Mavrogeni SI, Kitas GD, Dimitroulas T, Sfikakis PP, Seo P, Gabriel S, Patel AR, Gargani L, Bombardieri S, Matucci-Cerinic M, Lombardi M, Pepe A, Aletras AH, Kolovou G, Miszalski T, Van Riel P, Semb A, Gonzalez-Gay MA, Dessein P, Karpouzas G, Puntman V, Nagel E, Bratis K, Karabela G, Stavropoulos E, Katsifis G, Koutsogeorgopoulou L, Van Rossum A, Rademakers F, Pohost G, Lima JAC. Cardiovascular magnetic resonance in rheumatology: current status and recommendations for use. Int J Cardiol. 2016. https://doi.org/10.1016/j.ijcard.2016.04.158.
118. Mavrogeni S, Pepe A, Lombardi M. Evaluation of myocardial iron overload using cardiovascular magnetic resonance imaging. Hellenic J Cardiol. 2011.

119. Mavrogeni S, Sfikakis PP, Gialafos E, Bratis K, Karabela G, Stavropoulos E, Spiliotis G, Sfendouraki E, Panopoulos S, Bournia V, Kolovou G, Kitas GD. Cardiac tissue characterization and the diagnostic value of cardiovascular magnetic resonance in systemic connective tissue diseases. Arthritis Care Res. 2014. https://doi.org/10.1002/acr.22181.

120. Zandman-Goddard G, Peeva E, Shoenfeld Y. Gender and autoimmunity. Autoimmun Rev. 2007. https://doi.org/10.1016/j.autrev.2006.10.001.

121. Fairweather D, Frisancho-Kiss $S$, Rose NR. Sex differences in autoimmune disease from a pathological perspective. Am J Pathol. 2008. https://doi.org/10.2353/ajpath.2008.071008.

122. Pepe A, Meloni A, Rossi G, Midiri M, Missere M, Valeri G, Sorrentino F, D'Ascola DG, Spasiano A, Filosa A, Cuccia L, Dello lacono N, Forni G, Caruso V, Maggio A, Pitrolo L, Peluso A, De Marchi D, Positano V, Wood JC. Prediction of cardiac complications for thalassemia major in the widespread cardiac magnetic resonance era: a prospective multicentre study by a multi-parametric approach. Eur Heart J Cardiovasc Imaging. 2018. https://doi.org/10.1093/ehjci/jex012.

123. Meloni A, Positano V, Ruffo GB, Spasiano A, D'Ascola DG, Peluso A, Keilberg P, Restaino G, Valeri G, Renne S, Midiri M, Pepe A. Improvement of heart iron with preserved patterns of iron store by CMR-guided chelation therapy. Eur Heart J Cardiovasc Imaging. 2015. https://doi. org/10.1093/ehjci/jeu191.

124. Mavrogeni SI, Sfikakis PP, Markousis-Mavrogenis G, Bournia VK, Poulos G, Koutsogeorgopoulou L, Karabela G, Stavropoulos E, Katsifis G, Boki K, Vartela V, Kolovou G, Theodorakis G, Kitas GD. Cardiovascular magnetic resonance imaging pattern in patients with autoimmune rheumatic diseases and ventricular tachycardia with preserved ejection fraction. Int J Cardiol. 2019. https://doi.org/10.1016/j.ijcard.2018.10.067.

125. BidhulT S, Xanthis CG, LiljekvisT LL, Greil G, Nagel E, Aletras AH, Heiberg E, Hedström E. Validation of a new $\mathrm{t} 2 *$ algorithm and its uncertainty value for cardiac and liver iron load determination from MRI magnitude images. Magn Reson Med. 2016. https://doi.org/10.1002/mrm.25767.

126. Pennell DJ, Udelson JE, Arai AE, Bozkurt B, Cohen AR, Galanello R, Hoffman TM, Kiernan MS, Lerakis S, Piga A, Porter JB, Walker JM, Wood J. Cardiovascular function and treatment in $\beta$-thalassemia major: a consensus statement from the american heart association. Circulation. 2013. https://doi.org/10.1161/CIR.0b013e31829b2be6.

127. Pepe A, Gamberini MR, Missere M, Pistoia L, Mangione M, Cuccia L, Spasiano A, Maffei S, Cadeddu C, Midiri M, Borgna C, Meloni A. Gender differences in the development of cardiac complications: a multicentre study in a large cohort of thalassaemia major patients to optimize the timing of cardiac follow-up. Br J Haematol. 2018. https://doi.org/10. 1111/bjh.15125.

128. Mavrogeni S, Bratis K, Koutsogeorgopoulou L, Karabela G, Savropoulos E, Katsifis G, Raftakis J, Markousis-Mavrogenis G, Kolovou G. Myocardial perfusion in peripheral Raynaud's phenomenon. Evaluation using stress cardiovascular magnetic resonance. Int J Cardiol. 2017. https://doi.org/ 10.1016/j.ijcard.2016.11.242.

129. Chraibi S. Pericardial tamponade as the first manifestation of dermatopolymyositis. Ann Med Interne. (1998).

130. Mavrogeni S, Markousis-Mavrogenis G, Koutsogeorgopoulou L, Dimitroulas T, Bratis K, Kitas GD, Sfikakis P, Tektonidou M, Karabela G, Stavropoulos E, Katsifis G, Boki KA, Kitsiou A, Filaditaki V, Gialafos E, Plastiras S, Vartela V, Kolovou G. Cardiovascular magnetic resonance imaging pattern at the time of diagnosis of treatment naiive patients with connective tissue diseases. Int J Cardiol. 2017. https://doi.org/10. 1016/j.ijcard.2017.01.104.

131. Mavrogeni SI, Schwitter J, Gargani L, Pepe A, Monti L, Allanore Y, Matucci-Cerinic M. Cardiovascular magnetic resonance in systemic sclerosis:"Pearls and pitfalls." Semin Arthritis Rheum. 2017. https://doi. org/10.1016/.semarthrit.2017.03.020.

132. Kouranos V, Tzelepis GE, Rapti A, Mavrogeni S, Aggeli K, Douskou M, Prasad S, Koulouris N, Sfikakis P, Wells A, Gialafos E. Complementary role of CMR to conventional screening in the diagnosis and prognosis of cardiac sarcoidosis. JACC Cardiovasc Imaging. 2017. https://doi.org/10. 1016/j.jcmg.2016.11.019.

133. Kobayashi Y, Kobayashi H, Giles JT, Hirano M, Nakajima Y, Takei M. Association of tocilizumab treatment with changes in measures of regional 
left ventricular function in rheumatoid arthritis, as assessed by cardiac magnetic resonance imaging. Int J Rheum Dis. 2016. https://doi.org/10. 1111/1756-185X.12632.

134. Ingles J, Zodgekar PR, Yeates L, Macciocca I, Semsarian C, Fatkin D. Guidelines for genetic testing of inherited cardiac disorders. Heart Lung Circ. 2011. https://doi.org/10.1016/j.hlc.2011.07.013.

135. V.T. J.P., P. P.G., V.S.-Z. K.Y., V.D.B. M.P., Pregnancy, cardiomyopathies, and genetics. Cardiovasc Res. 2014.

136. Miani D, Taylor M, Mestroni L, D'Aurizio F, Finato N, Fanin M, Brigido S, Proclemer A. Sudden death associated with Danon disease in women. Am J Cardiol. 2012. https://doi.org/10.1016/j.amjcard.2011.09.024.

137. Nordin S, Kozor R, Baig S, Abdel-Gadir A, Medina-Menacho K, Rosmini S, Captur G, Tchan M, Geberhiwot T, Murphy E, Lachmann R, Ramaswami U, Edwards NC, Hughes D, Steeds RP, Moon JC. Cardiac phenotype of prehypertrophic fabry disease. Circ Cardiovasc Imaging. 2018. https:// doi.org/10.1161/CIRCIMAGING.117.007168.

138. Yancy CW, Jessup M, Bozkurt B, Butler J, Casey DE, Drazner MH, Fonarow GC, Geraci SA, Horwich T, Januzzi JL, Johnson MR, Kasper EK, Levy WC, Masoudi FA, McBride PE, McMurray JJV, Mitchell JE, Peterson PN, Riegel B, Sam F, Stevenson LW, Tang WHW, Tsai EJ, Wilkoff BL. 2013 ACCF/AHA guideline for the management of heart failure: a report of the american college of cardiology foundation/american heart association task force on practice guidelines. Circulation. 2013. https://doi.org/10.1161/CIR. 0b013e31829e8776.

139. Sen-Chowdhry S, Jacoby D, Moon JC, McKenna WJ. Update on hypertrophic cardiomyopathy and a guide to the guidelines. Nat Rev Cardiol. 2016. https://doi.org/10.1038/nrcardio.2016.140.

140. Ponikowski P, Voors AA, Anker SD, Bueno H, Cleland JGF, Coats AJS, Falk V, González-Juanatey JR, Harjola VP, Jankowska EA, Jessup M, Linde C, Nihoyannopoulos P, Parissis JT, Pieske B, Riley JP, Rosano GMC, Ruilope LM, Ruschitzka F, Rutten FH, Van Der Meer P, Sisakian HS, Isayev E, Kurlianskaya A, Mullens W, Tokmakova M, Agathangelou P, Melenovsky $\checkmark$, Wiggers $H$, Hassanein M, Uuetoa T, Lommi J, Kostovska ES, Juilliere Y, Aladashvili A, Luchner A, Chrysohoou C, Nyolczas N, Thorgeirsson G, Weinstein JM, Di Lenarda A, Aidargaliyeva N, Bajraktari G, Beishenkulov M, Kamzola G, Abdel-Massih T, Celutkiene J, Noppe S, Cassar A, Vataman E, AbirKhalil S, van Pol P, Mo R, Straburzynska-Migaj E, Fonseca C, Chioncel O, Shlyakhto E, Zavatta M, Otasevic P, Goncalvesova E, Lainscak M, Molina BD, Schaufelberger M, Suter T, YIImaz MB, Voronkov L, Davies
C. 2016 ESC Guidelines for the diagnosis and treatment of acute and chronic heart failure. Eur Heart J. 2016. https://doi.org/10.1093/eurhe artj/ehw128.

141. Florian A, Rösch S, Bietenbeck M, Engelen M, Stypmann J, Waltenberger J, Sechtem U, Yilmaz A. Cardiac involvement in female Duchenne and Becker muscular dystrophy carriers in comparison to their first-degree male relatives: a comparative cardiovascular magnetic resonance study. Eur Heart J Cardiovasc Imaging. 2016. https://doi.org/10.1093/ehjci/ jev161.

142. Thompson RB, Chow K, Khan A, Chan A, Shanks M, Paterson I, Oudit GY. $T<$ sub $>1</$ sub $>$ Mapping with CMR is highly sensitive for fabry disease independent of hypertrophy and gender. Circ Cardiovasc Imaging. 2013.

143. Ashrafi R, Curtis SL. Heart disease and pregnancy. Cardiol Therapy. 2017;6:157-73. https://doi.org/10.1007/s40119-017-0096-4.

144. Strizek B, Jani JC, Mucyo E, De Keyzer F, Pauwels I, Ziane S, Mansbach AL, Deltenre P, Cos T, Cannie MM. Safety of MR imaging at 1.5 T in fetuses: a retrospective case-control study of birth weights and the effects of acoustic noise. Radiology. 2015. https://doi.org/10.1148/radiol.14141 382.

145. Ray JG, Vermeulen MJ, Bharatha A, Montanera WJ, Park AL. Association between MRI exposure during pregnancy and fetal and childhood outcomes. JAMA J Am Med Assoc. 2016. https://doi.org/10.1001/jama. 2016.12126.

146. Prola-Netto J, Woods M, Roberts VHJ, Sullivan EL, Miller CA, Frias AE, Oh KY. Gadolinium chelate safety in pregnancy: Barely detectable gadolinium levels in the juvenile nonhuman primate after in utero exposure. Radiology. 2018. https://doi.org/10.1148/radiol.2017162534.

147. Contrast Media Safety Committee. ESUR Guidelines on Contrast Agents v10.0. Eur Soc Urogenit Radiol. 2018.

148. Jain C. ACOG Committee Opinion No. 723: quidelines for diagnostic imaging during pregnancy and lactation. Obstetr Gynecol. 2019. https://doi.org/10.1097/AOG.0000000000003049.

\section{Publisher's Note}

Springer Nature remains neutral with regard to jurisdictional claims in published maps and institutional affiliations.
Ready to submit your research? Choose BMC and benefit from:

- fast, convenient online submission

- thorough peer review by experienced researchers in your field

- rapid publication on acceptance

- support for research data, including large and complex data types

- gold Open Access which fosters wider collaboration and increased citations

- maximum visibility for your research: over $100 \mathrm{M}$ website views per year

At BMC, research is always in progress.

Learn more biomedcentral.com/submissions 